\title{
Effect of prototypical inducers on ligand activated nuclear receptor regulated drug disposition genes in rodent hepatic and intestinal cells
}

\author{
Philip MARTIN ${ }^{1, *}$, Robert RILEY ${ }^{2}$, Paul THOMPSON ${ }^{3}$, Dominic WILLIAMS ${ }^{1}$, David BACK ${ }^{1}$, Andrew OWEN ${ }^{1}$ \\ ${ }^{1}$ Department of Pharmacology and Therapeutics, The University of Liverpool, Pembroke Place, Liverpool, L69 3GF, UK; ${ }^{2}$ Department of \\ Physical and Metabolic Science, AstraZeneca Charnwood, Leicestershire, LE11 5RH, UK; ${ }^{3}$ School of Biomedical Sciences, The Univer- \\ sity of Ulster, Cromore Road, Coleraine, Co. Londondarry, BT52 1SA, UK
}

\begin{abstract}
Aim: The aim of this study was to investigate the impact on expression of mRNA and protein by paradigm inducers/activators of nuclear receptors and their target genes in rat hepatic and intestinal cells. Furthermore, assess marked inter laboratory conflicting reports regarding species and tissue differences in expression to gain further insight and rationalise previously observed species differences between rodent and human based systems.

Methods: Quantitative real time-polymerase chain reaction (QRT-PCR) and immunoblots were used to assess messenger RNA (mRNA) and protein expression for CYP2B2, CYP3A1, CYP3A2, CYP3A9, ABCB1a, ABCB1b, ABCC1, ABCC2, pregnane X receptor (PXR), farnesoid $X$ receptor (FXR) and constituitive androstane receptor (CAR) in rat hepatoma cell line H411E, intestinal cells, lec-6, and rat primary hepatocytes, in response to exposure for $18 \mathrm{~h}$ with prototypical inducers.

Results: Dexamethasone (DEX) and pregnenolone 16 $\alpha$ carbonitrile (PCN) significantly induced PXR, CYP3A9, ABCB1a and ABCB1b. However, when co-incubated, DEX appeared to restrict PCN-dependent induction. Chenodeoxycholic acid (CDCA) was the only ligand to induce FXR in all three cell types. Despite previously reported species differences between PCN and rifampicin (RIF), both compounds exhibited a similar profile of induction.

Conclusion: Data presented herein may explain some of the discrepancies previously reported with respect to species differences from different laboratories and have important implications for study design.
\end{abstract}

Keywords: nuclear receptors; hepatic cells; intestinal cells; prototypical inducers; rodents; dexamethasone; pregnenolone 16 $\alpha$ carbonitrile; cytochrome $\mathrm{P} 450$; pregnane $\mathrm{X}$ receptor; constituitive androstane receptor

Acta Pharmacologica Sinica (2010) 31: 51-65; doi: 10.1038/aps.2009.187

\section{Introduction}

Constituitive androstane receptor (CAR), pregnane $X$ receptor(PXR), and farnesoid $X$ receptor (FXR) are key transcription factors regulating transcription of drug metabolising enzymes and transporters in response to prototypical inducers and activators such as PCN (rodent PXR), RIF (human PXR), PB (CAR) and CDCA (FXR). We have previously shown the impact of various prototypical inducers on expression of human isoforms of their genes ${ }^{[1]}$. The purpose of this study was to investigate the similarity and differences with rodent homologues using identical methodology.

Several important rodent homologues of human drug metabolising enzymes of CYP3A4/5 and CYP2B6 have been

\footnotetext{
* To whom correspondence should be addressed.

E-mail P.Martin@liverpool.ac.uk

Received 2009-07-20 Accepted 2009-12-01
}

characterised in rodents: CYP3A $1^{[2,3]}, \mathrm{CYP} 3 \mathrm{~A} 2^{[4]}, \mathrm{CYP} 3 \mathrm{~A} 9^{[5]}$ and CYP3A18 ${ }^{[6,7]}$. These CYPs are inducible by glucocorticoids such as DEX, antibiotics such as RIF and other steroids such as $\mathrm{PCN}^{[8-10]}$. In addition, CYP2B2 has been studied extensively ${ }^{[11-14]}$ and is known to be induced by many structurally divergent compounds ${ }^{[15]}$ incuding phenobarbital (PB).

PXR and CAR regulate overlapping sets of genes in a tissue specific fashion. In rodents, common activators of PXR and CAR upregulate ABCC2 in the liver via CAR, and in the intestine via PXR, while ABCB1a and $A B C B 1 b$ are upregulated via PXR in the liver and intestine, with an additional effect via CAR in the intestine confined to ABCB1a ${ }^{[16]}$. A comparison of the PXR sequences from different mammalian species indicates that the PXR proteins share less than $80 \%$ amino acid identity in their ligand binding domains (LBD), while the DNA binding domain (DBD) is $\sim 95 \%$ similar ${ }^{[17]}$. The species differences in these LBDs are believed to be responsible for the 
selectivity in ligand binding, and thus the marked differences in the induction profiles between species ${ }^{[18]}$.

FXR is a ligand-activated transcription factor regulating cholesterol and fatty acid metabolism and also functions as an endogenous sensor for bile acids ${ }^{[19-21]}$. The relative contribution of FXR to induction of disposition genes is still unclear. However, the observation that lithocholic acid (LCA) induces CYP3A in PXR-null mice and that FXR activates human CYP3A4 promoter in vitro, implies CYP3A gene expression may also be controlled by FXR ${ }^{[22,23]}$. Furthermore, ABCC2 has also been shown to be a target of FXR ${ }^{[24,25]}$.

To date, analysis of gene expression and regulation of drug disposition genes utilise either immortalised or primary cell cultures. However, important differences have been reported between laboratories utilising the same strains of cells ${ }^{[26,27]}$. The aim of this study was to investigate the impact of phenobarbital (PB:CAR), CDCA (FXR), PCN (rodent PXR) and RIF (human PXR) on mRNA and protein expression of ABCB1a, ABCB1b, ABCC1, АВCC2, CYP2B2, CYP3A1, CYP3A2, CYP3A9, PXR, CAR, and FXR in rat hepatic and intestinal cell lines (H411E and Iec-6) and rat primary hepatocytes.

\section{Materials and methods Cell culture}

Rat hepatoma cell line H411E and rat intestinal cell line, Iec-6, were purchased from the American Tissue Culture Collection (ATCC, USA) and maintained in Dulbecco's modified Eagle's medium (DMEM; Sigma-Aldrich company, UK) supplemented with $10 \%$ fetal bovine serum (FBS; Bio-Whittaker, Europe). Cell lines were incubated at $37^{\circ} \mathrm{C}$ and $5 \% \mathrm{CO}_{2}$ and subcultured every 4 days.

For isolation of fresh rat primary hepatocytes, rats were anaesthetised and the liver isolated and perfused for $10 \mathrm{~min}$ with wash buffer containing 10\% $v / v$ Hanks' balanced salt solution (HBSS; Sigma, UK), 0.138\% w/v Hepes (Sigma, UK) and $0.5 \% v / v$ sodium hydrocarbonate (Sigma, UK) in deionised $\mathrm{H}_{2} \mathrm{O}$. The rat liver was further perfused for 6-10 min with $500 \mathrm{~mL}$ of pre-warmed $\left(37^{\circ} \mathrm{C}\right)$ digestion buffer containing wash buffer, $0.5 \% v / v$ calcium chloride, $250 \mathrm{mg}$ Collagenase A (Sigma, UK) and $34 \mathrm{mg}$ trypsin inhibitor (Sigma, UK). The digested rat liver was then placed into a petri dish containing $20 \mathrm{mg}$ DNase and $200 \mathrm{~mL}$ wash buffer. The residual tissue was removed and the cells filtered through a $125 \mu \mathrm{m}$ nylon blotting cloth and resuspended in DNase wash buffer and allowed to settle for $10 \mathrm{~min}$, the supernatant was then removed and cells were washed and centrifuged at $50 \times g$ for 2 min and finally resuspended in wash buffer. Viability was determined based on Trypan blue exclusion ${ }^{[28,29]}$ and found to be $85 \%-90 \%$ viable.

\section{Assessment of protein binding}

Equilibrium dialysis was used to determine protein binding of PB, CDCA, PCN, and RIF (all compounds purchased from Sigma, UK) within the culture supernatant. Briefly, Dianorm dialysis membranes $(\mathrm{GmbH}$, Munich, Germany) with molecular weight cut-off (MWC) of 5000 were soaked for $1 \mathrm{~h}$ in DMEM (Sigma-Aldrich, UK). PB, CDCA, PCN, and RIF were then individually added to DMEM containing 10\% FBS (H411E, Iec-6 and primary hepatocyte media) to a final concentration of $10 \mu \mathrm{mol} / \mathrm{L}$. An aliquot $(1 \mathrm{~mL})$ was then dispensed into one side of the dialysis block divided by the presoaked membrane, the other side containing control (without additions) media. The dialysis block was then sealed and rotated in a water bath for $24 \mathrm{~h}$ at $37^{\circ} \mathrm{C}$. A $200 \mu \mathrm{L}$ aliquot was subsequently removed from the control side of the dialysis block and placed in quench tubes containing $200 \mu \mathrm{L}$ of ice-cold methanol. After centrifugation at $400 \times \mathrm{g}$ for $20 \mathrm{~min}$, the supernatant was transferred into 96-well plates and analysed using liquid chromatography/mass spectrophotometry (LC-MS/ MS) (AstraZeneca in-house methodology).

\section{Treatment of cell lines for induction}

H411E and Iec- 6 were seeded into Nunclon ${ }^{\mathrm{TM}}$ Surface 6 well plates (Nunc A/S, Denmark) at a density of $5 \times 10^{6}$ (per well) containing DMEM and FBS (10\%). Initial experiments assessed the effect of DEX on expression of CYP3A9, ABCB1a, $A B C B 1 b$, and PXR and the inducibility of CYP3A9, ABCB1a, ABCB1b, and PXR by PCN in H411E and Iec- 6 cells. After 24 hours the prototypical inducers, $\mathrm{PB}, \mathrm{CDCA}, \mathrm{PCN}$, and RIF were added to give final concentrations of $0.01,0.1,1.0,10$, and $100 \mu \mathrm{mol} / \mathrm{L}$. The control used was the test compound vehicle, methanol for RIF or Dimethyl sulfoxide (DMSO) $(0.1 \% v / v$ for both vehicles) for $\mathrm{PB}, \mathrm{CDCA}$ or PCN. Cells were incubated for a further 18 hours at $37^{\circ} \mathrm{C}$ and $5 \% \mathrm{CO}_{2}$, total RNA isolated and cDNA constructed as described previously ${ }^{[30]}$.

\section{Treatment of rat primary hepatocytes for induction}

Rat primary hepatocytes were seeded at a density of $1 \times 10^{6}$ per well into $10 \%$ FBS supplemented DMEM in Nunclon ${ }^{\mathrm{TM}}$ Surface 6 well plates (Nunc A/S, Denmark) and allowed to grow for $24 \mathrm{~h}$ prior to treatment. Test compounds, PB, CDCA, PCN and RIF were added to give a final concentration of 1.0 $\mu \mathrm{mol} / \mathrm{L}$ and a time course was conducted. Cells were then incubated at $37^{\circ} \mathrm{C}$ and $5 \% \mathrm{CO}_{2}$ and sampled at $0,2,4,6$, and 18 hours. DMSO treated controls were used for PB, CDCA, PCN and methanol treated controls were used for RIF $(0.1 \% v / v$ for both vehicles).

\section{Toxicity}

All test compounds were assayed for toxicity by 3-(4,5-dimethylthiazol-2-yl)-2,5-diphenyl-tetrazolium bromide (MTT) assay $^{[31]}$ for both cell lines at final concentrations of 0.01 to 100 $\mu \mathrm{mol} / \mathrm{L}$. These assays were performed at $18 \mathrm{~h}$ to assess cell death at the point of analysis. Toxicity of test compounds was also assessed after 5 days as toxic concentrations would not necessarily be evident after 18 hours.

\section{Quantitative real-time PCR}

For H411E, Iec-6 and rat primary hepatocytes, total RNA was isolated utilising Tri-reagent (Sigma, UK) and cDNA constructed as previously described ${ }^{[30]}$. Real-time PCR assays were developed for quantification relative to $\beta$-actin (house- 
keeping gene) for each transcript in each cell set (H411E, Iec-6, and primary hepatocytes). Formation of primer dimer was optimised and eliminated out of the reaction to ensure no false positive amplification data was incorporated as a result of non-specific intercalation of picogreen (Molecular Probes, Paisley, UK). Relative expression against housekeeping gene $\beta$-actin $\left(\Delta \Delta \mathrm{C}_{\mathrm{T}}\right)$ of transcripts were performed in an Opticon2 ${ }^{\mathrm{TM}}$ Fluorescence Detector (MJ Research, Bio-Rad, Hertfordshire, $\mathrm{UK})$. Amplification was performed in a final reaction volume of $25 \mu \mathrm{L}$ utilising pico green intercalating fluorescence dye. The reaction mixture consisted of, $2.5 \mu \mathrm{L} 10 \times$ Taqman Buffer II, 0.5U Taq polymerase, $1.25 \mu \mathrm{mol} / \mathrm{L} \mathrm{MgCl}_{2}$ (Amplitaq Gold; Applied Biosystems, UK), $1.25 \mu \mathrm{mol} / \mathrm{L}$ dNTPs (Promega, UK), $20 \mathrm{ng}$ cDNA, $0.5 \mu \mathrm{L}$ pico green (final concentration 1:5000) and $0.03 \mu \mathrm{mol} / \mathrm{L}$ of forward and reverse primer, with the exception of constitutive androstane receptor and CYP3A9 which required $0.3 \mu \mathrm{mol} / \mathrm{L}$ (final concentration) and nuclease-free water was added to a final volume of $25 \mu \mathrm{L}$ (Sigma-Aldrich, UK). Primer sequences and full assay conditions can be found on supplementary Table 1 and Table 2 respectively.

\section{Immunoblotting}

Western blotting analysis was performed in parallel with quantitative real time PCR using crude protein homogenates for CYPs, and for transporter proteins, crude membrane fractions which were purified as described previously ${ }^{[32]}$. In all cases, protein concentration was determined using the bicinchoninic acid assay $(\mathrm{BCA})^{[33]}$. Samples were normalised to 5 $\mu \mathrm{g} / \mu \mathrm{L}$ and stored at $-80^{\circ} \mathrm{C}$ prior to use. Western blotting of all proteins was performed using NuPage 4\%-12\% Bis-Tris Gels (Invitrogen, Paisley, UK). Blotting was conducted using nitrocellulose membranes and iBlot ${ }^{\mathrm{TM}}$ Gel Transfer System (Invitrogen, UK), as per manufacturer's instructions, and membranes were blocked in 10\% non-fat-dried milk (NFDM) overnight at $4{ }^{\circ} \mathrm{C}$.

For CYP2B2, CYP3A1, CYP3A2, CYP3A9 (1:1000), mouse anti-rat CYP2B2 [sc-53242 (Santa Cruz Biotechnology, USA)], rabbit anti-rat CYP3A1 [AB1253 (Chemicon, USA)], rabbit anti-rat CYP3A2 [458223 (BD Gentest, USA)] and rabbit antirat CYP3A9 [AB1276 (Chemicon, USA)] were diluted in 0.1\% T-TBS and 2\% NFDM. For ABCB1a/b (1:4000), ABCC1 and ABCC2 (1:1000), mouse anti-rat ABCC2 [ab3373 (M2 III-6) (abcam, UK)], mouse anti rat ABCC1 [ab24102 (MRPm5) (abcam, UK)], goat anti rat P-gp $[\operatorname{mdr}(\mathrm{C}-19)$ (Santa Cruz Biotechnology, USA)] were diluted in $0.05 \%$ T-TBS. $\beta$-actin loading control was used for all proteins (anti $\beta$-actin (1:5000) (Sigma, UK). All primary antibodies were incubated for $2 \mathrm{~h}$ at room temperature and all intermediate wash steps were performed with $0.05 \%$ T-TBS.

Horse radish peroxidise (HRP) conjugated secondary antibodies; STAR88P Donkey anti-sheep HRP conjugated (Serotec, USA), ab6701 Donkey anti-rabbit HRP conjugated (abcam, UK), P0449: rabbit anti-goat HRP conjugated (DakoCytomation, Denmark), sheep anti-mouse HRP conjugated (Amersham Biosciences, UK) were diluted 1:10000 and incubated for 1 hour at room temperature in 2\% NFDM and 0.03\% T-TBS.
All subsequent washing steps were performed with $0.05 \%$ $\mathrm{T}$-TBS, with the exception of $\mathrm{ABCB} 1 \mathrm{a} / \mathrm{b}$ which required $0.1 \%$ T-TBS.

Protein band visualisation was performed using enhanced chemiluminescence (ECL) technology (PerkinElmer, USA) and quantification was achieved using BioRad GS710 scanner and BioRad Quantity One ${ }^{\mathrm{TM}}$ densitometric analysis software (BioRad, USA). Optical density and relative protein expression of bands was determined against $\beta$-actin loading controls. Background saturation of ECL treated nitrocellulose membranes was corrected by subtraction of measurements taken from random sections of membrane $(n=4)$ and subtracted from protein band density.

\section{Statistical and data analysis}

All reported data are for 18 hour incubations. The minimum concentration at which induction was observed and maximum fold change (excluding toxic concentrations) versus control are presented throughout this manuscript. Caution was taken in interpretation from data generated with concentrations of test compound shown to be toxic at 5 days for H411E and Iec-6. Specifically, concentrations that produced toxicity after 5 days are illustrated in the figures as dashed lines and statistical analysis is only presented for data at which significant induction was observed below this threshold. Therefore robust $\mathrm{EC}_{50}$ and $E_{\max }$ estimates were compromised and thus not used. Normality was assessed using a Shapiro-Wilk statistical test. Differences in mRNA and protein expression were assessed using a paired $t$-test. Logarithmic and/or linear regression was used to determine the relationship between change in mRNA and protein in cell lines.

\section{Results}

\section{Cell line characterisation}

All CYPs were expressed at higher levels in liver tissue compared to intestine and primary hepatocytes (Figure 1A, 1B, and $1 \mathrm{C})$, whereas transporters $\mathrm{ABCB} 1 \mathrm{a}$ and $\mathrm{ABCB} 1 \mathrm{~b}$ were expressed at relatively higher levels in intestinal tissue compared to liver and primary hepatocytes (Figure 1D, 1E, and $1 F)$. Lower basal levels of expression of nuclear receptors were found in the intestinal tissue compared to liver tissue and primary cells, specifically for PXR (Figure 1G, 1H, and 1I). Basal level of expression of transcripts were approximately 13 fold (NRs), 14 fold (transporters) and 6 fold (CYPs) higher in liver tissue compared to H411E and primary hepatocytes (Figure 1a, $\mathrm{d}$ and $\mathrm{g}$ respectively). 8 fold (NRs), 14 fold (transporters) and 4 fold (CYPs) higher in intestinal tissue compared Iec-6 and primary hepatocytes (Figure 1B, 1E, and 1H). Despite some minor oscillations in basal level of expression during passage, all transcripts were found to be stable from passage 5 to passage 21 after receipt from ATCC for both cell lines. However, for analysis, cell lines were only used between passage 11 and 13.

\section{Toxicity}

After $18 \mathrm{~h}$, there was no significant toxicity observed for any 

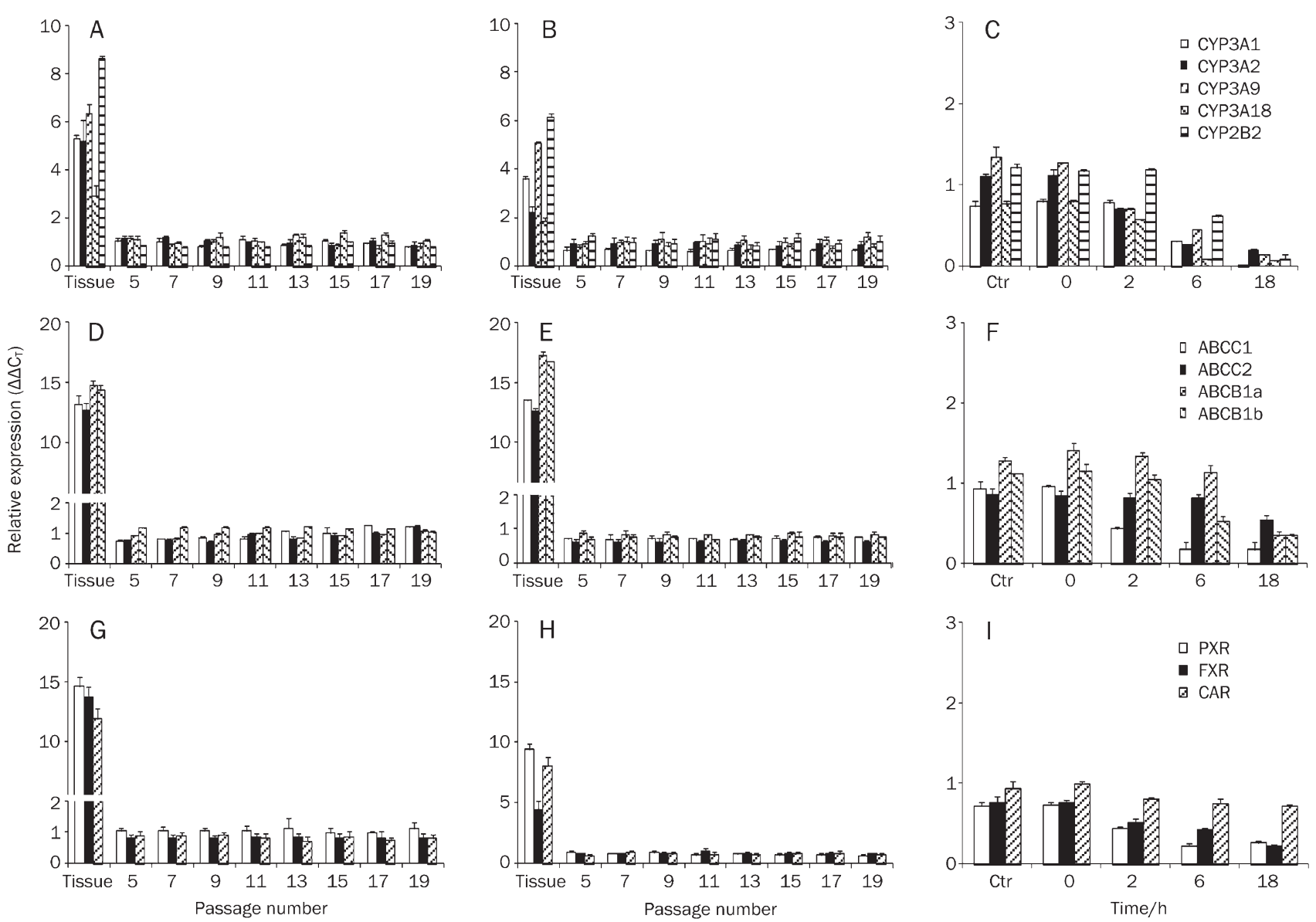

Figure 1. Basal level of expression and stability of CYPs, transporters $(A B C)$ and nuclear hormone receptors in rodent liver versus rodent hepatic cell line $\mathrm{H} 411 \mathrm{E}(\mathrm{A}, \mathrm{D}$, and $\mathrm{G})$ and rodent intestinal tissue versus rodent intestinal cell line lec-6 $(\mathrm{B}, \mathrm{E}$, and $\mathrm{H})$ during passage. Basal level of expression and stability of CYPs, transporters and nuclear hormone receptors in rat primary hepatocytes over time. Data are the mean \pm SD. $n=4$ experiments conducted in duplicate.

test compounds. However, after 5 days significant toxicity was detected for both H411E and Iec-6 (data not shown) implying that induction studies above certain concentrations may not be physiologically relevant ie for H411E, PB, PCN, CDCA, and RIF were all toxic at $100 \mu \mathrm{mol} / \mathrm{L}(P<0.0001)$. For Iec-6, CDCA, and PB were toxic at $10 \mu \mathrm{mol} / \mathrm{L}(P=0.0001$ and $P<0.0001$ respectively) and PCN and RIF at $100 \mu \mathrm{mol} / \mathrm{L}$ ( $P=0.0027$ and $P<0.0001 P=0.0027$ respectively).

\section{Protein binding}

For DMEM containing $10 \%$ FBS, PB, PCN, RIF, and CDCA were determined as $98 \%, 97 \%, 98 \%$, and $82 \%$ unbound respectively, indicating low levels of binding to FBS and a similar free drug concentration was present for incubations for all cell types.

\section{Effects of DEX on CYP3A9, ABCB1a, ABCB1b, and PCN}

DEX was a potent inducer of all transcripts in H411E (Figure 2A) and Iec-6 (Figure 2B). Concentration dependent induction was observed for all transcripts in both cell lines, with significant induction for ABCB1a and ABCB1b in H411E and
ABCB1a, ABCB1b, and CYP3A9 in Iec-6 at $0.01 \mu \mathrm{mol} / \mathrm{L}$. Significant induction of PXR was detected at $0.1 \mu \mathrm{mol} / \mathrm{L}$ DEX in both cell lines. With the exception of ABCB1a in H411E $(10 \mu \mathrm{mol} / \mathrm{L})$, all transcripts were maximally induced at 100 $\mu \mathrm{mol} / \mathrm{L} \mathrm{DEX}$.

In H411E and Iec-6 cells, PCN significantly induced CYP3A9 mRNA (Figures 2C and 2D), ABCB1a (Figures 2E and 2F), ABCB1b (Figures 2G and 2H) and PXR (Figures 2I and 2J) when compared to DEX-free control. However, when DEX was included in the culture media no significant induction of ABCB1b in H411E (Figure 2G) or CYP3A9 in Iec-6 (Figure 2D) was observed compared to DEX-free control.

Induction of PXR, FXR, and CAR mRNA in H411E, lec-6, and primary hepatocytes

A summary of the impact on all genes of interest by prototypical inducers in H411e, lec-6, and rat primary hepatocytes can be found in Table 1. The impact of CDCA, PCN, PB, and RIF on PXR, FXR, and CAR mRNA expression in H411E, Iec-6, and primary hepatocytes are shown in Figure 3. CDCA significantly increased expression of PXR, FXR, and CAR in H411E 

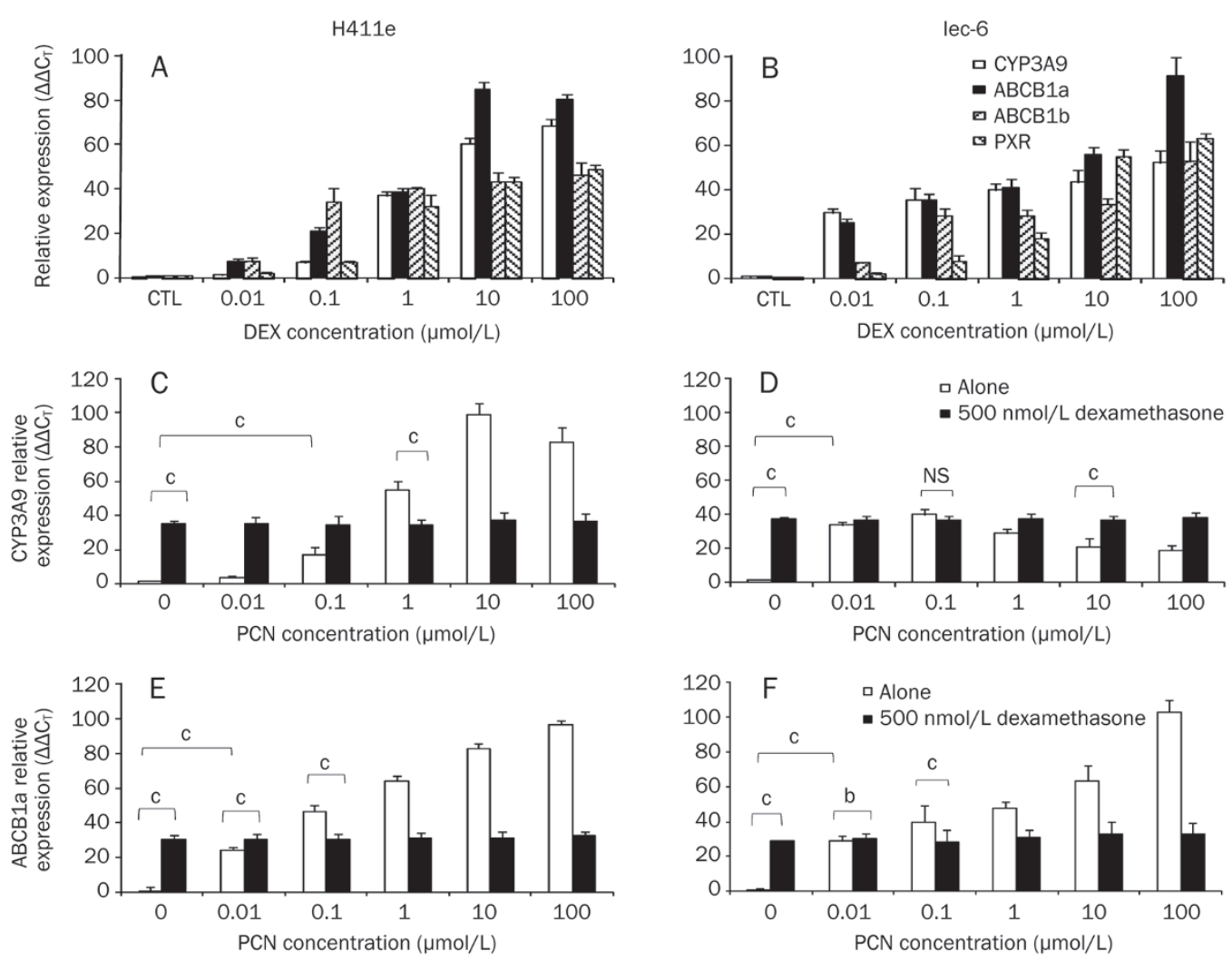

Figure 2. Implications of using dexamethasone (DEX) as a media supplement (A, B). Impact of dexamethasone (DEX) (0-100 $\mu \mathrm{mol} / \mathrm{L}$ ) on mRNA expression of CYP3A9, ABCB1a, ABCB1b, and pregnane $X$ receptor (PXR) in $\mathrm{H} 411 \mathrm{E}$ and lec-6 $(\mathrm{C}-\mathrm{H})$. Impact of dexamethasone (DEX) $(500 \mathrm{nmol} / \mathrm{L})$ on inducibility of CYP3A9 (C, D), ABCB1a (E, F), ABCB1b (G, H) and pregnane $X$ receptor (PXR) (I, J) by pregneno-
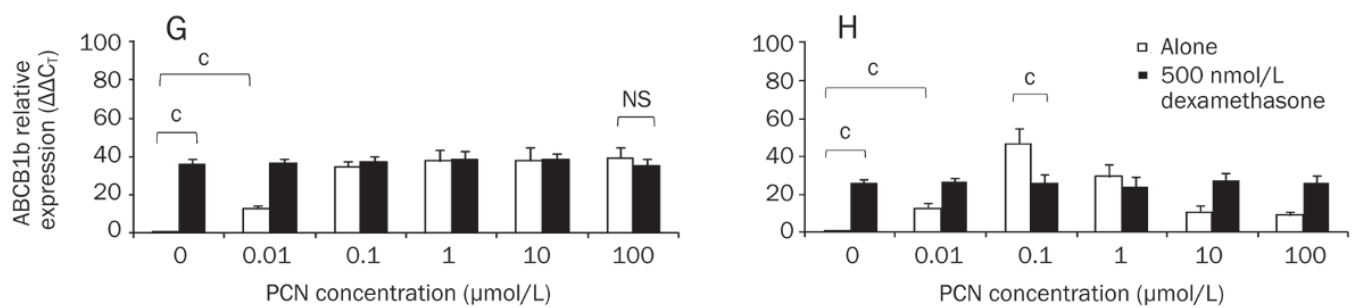
lone $16 \alpha$-carbonitrile (PCN) in H411E and lec- 6 cells. Data are mean $\pm S D$ of four experiments conducted in duplicate. For clarity, not all statistical analyses are given: ${ }^{b} P<0.05,{ }^{\circ} P<0.01$. For each transcript, a significant increase in expression was

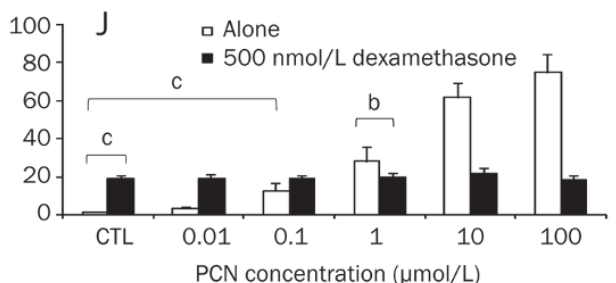
observed at concentrations $\leq 1$ $\mu \mathrm{mol} / \mathrm{L}$ when cells were incubated with pregnenolone $16 \alpha$ carbonitrile (PCN) alone, which would not have been observed when dexamethasone (DEX) was incorporated into the media.

(Figure 3A) and Iec-6 (Figure 3B), but only for FXR and CAR in primary hepatocytes (Figure $3 \mathrm{C}$ ). PCN caused significant induction of PXR and CAR in H411E (Figure 3D), Iec-6 (Figure $3 \mathrm{E}$ ) in primary hepatocytes (Figure 3F). However, there was no significant increase of FXR by PCN in any cells used. For $\mathrm{PB}$, there was no significant increase in mRNA expression for FXR in H411E, Iec-6 or primary hepatocytes (Figures 3G, 3H, and 3 I respectively). However, significant induction of PXR and CAR was observed for all three cell types. This effect by $\mathrm{PB}$ was more marked with respect to magnitude of fold change for CAR in Iec-6 cells (Figure 3H) compared to H411E and primary hepatocytes. RIF upregulated FXR, PXR, and CAR in H411E (Figure 3J), PXR and CAR in Iec-6 (Figure 3K) and primary hepatocytes (Figure 3L).
Induction of CYP2B2, CYP3A1, CYP3A2, and CYP3A9 mRNA in H411E, lec-6, and primary hepatocytes

The effect of CDCA, PCN, PB, and RIF on mRNA expression of CYP2B2, CYP3A1, CYP3A2, and CYP3A9 can be seen in Figure 4. Statistical analysis is only given for the lowest concentration at which a significant induction was observed. CDCA significantly upregulated CYP2B2, CYP3A1, and CYP3A9 in H411E (Figure 4A), CYP2B2 and CYP3A1 in Iec-6 (Figure 4b) and CYP2B2, CYP3A1, CYP3A2, and CYP3A9 in primary hepatocytes (Figure 4C). For PCN, all CYPs were significantly increased at $0.1 \mu \mathrm{mol} / \mathrm{L}$ in H411E (Figure 4D), whereas in Iec-6 (Figure 4E), CYP3A1 and CYP3A9 were induced at 0.01 $\mu \mathrm{mol} / \mathrm{L}, \mathrm{CYP} 2 \mathrm{~B} 2$ at $0.1 \mu \mathrm{mol} / \mathrm{L}$ and CYP3A2 at $10 \mu \mathrm{mol} / \mathrm{L}$ $\mathrm{PCN}$. In addition, all CYP transcripts were induced in pri- 
Table 1. Summary of the impact of prototypical inducers (Chenodeoxycholiic acid; CDCA, Pregnane 16 $\alpha$-carbonitrile; PCN, Phenobarbital; PB and Rifampicin; RIF), on gene expression in H411e, lec-6, and rat primary hepatocytes. For clarity, statistical analyses for cell lines H411e and lec-6 are given only for the lowest concentration at which a significant difference was observed. For primary hepatocytes, the incubation time (in hours) when significant induction was detected: ${ }^{\mathrm{b}} P<0.05,{ }^{\mathrm{c}} P<0.01$.

\begin{tabular}{|c|c|c|c|c|c|c|c|c|c|c|c|c|}
\hline \multirow[b]{2}{*}{ Gene } & \multicolumn{4}{|c|}{$\begin{array}{c}\mathrm{H} 411 \mathrm{e} \\
\text { Test compound }(\mu \mathrm{mol} / \mathrm{L})\end{array}$} & \multicolumn{4}{|c|}{$\begin{array}{c}\text { lec-6 } \\
\text { Test compound }(\mu \mathrm{mol} / \mathrm{L})\end{array}$} & \multicolumn{4}{|c|}{$\begin{array}{l}\text { Primary hepatocytes } \\
\text { Test compound at } 1 \mu \mathrm{mol} / \mathrm{L} \\
\text { (Incubation time in hours) }\end{array}$} \\
\hline & CDCA & $\mathrm{PCN}$ & PB & RIF & CDCA & PCN & PB & RIF & CDCA & PCN & PB & RIF \\
\hline CYP2B2 & $0.1^{\mathrm{c}}$ & $0.1^{\mathrm{c}}$ & $10^{\mathrm{b}}$ & NS & $1^{c}$ & $0.1^{c}$ & NS & NS & $2^{c}$ & $2^{c}$ & $2^{b}$ & NS \\
\hline CYP3A1 & $10^{b}$ & $0.1^{c}$ & $10^{\mathrm{b}}$ & $1^{c}$ & $0.1^{c}$ & $0.01^{c}$ & $1^{c}$ & $0.1^{b}$ & $2^{c}$ & $2^{b}$ & $2^{c}$ & $2^{c}$ \\
\hline СYР3А2 & NS & $0.1^{c}$ & $10^{\mathrm{b}}$ & $1^{c}$ & NS & $10^{c}$ & $1^{b}$ & $1^{c}$ & $2^{c}$ & $2^{c}$ & $2^{c}$ & $2^{c}$ \\
\hline СҮРЗАЯ & $0.1^{\mathrm{c}}$ & $0.1^{c}$ & $10^{c}$ & $0.01^{b}$ & NS & $0.01^{c}$ & $0.01^{c}$ & $0.1^{\mathrm{c}}$ & $2^{c}$ & $2^{c}$ & $2^{c}$ & $2^{c}$ \\
\hline ABCC1 & $1^{c}$ & $1^{c}$ & NS & $1^{c}$ & $1^{c}$ & $1^{c}$ & NS & $1^{b}$ & $4^{b}$ & $2^{c}$ & $2^{b}$ & $4^{b}$ \\
\hline ABCC2 & $1^{b}$ & $1^{c}$ & $10^{c}$ & $1^{c}$ & NS & NS & $1^{\mathrm{b}}$ & $1^{c}$ & $2^{c}$ & $2^{b}$ & $2^{b}$ & $2^{b}$ \\
\hline ABCB1a & $0.01^{c}$ & $0.01^{c}$ & $0.01^{c}$ & $0.01^{c}$ & $0.01^{c}$ & $0.01^{c}$ & $0.01^{c}$ & $0.01^{c}$ & $2^{b}$ & $2^{c}$ & $2^{c}$ & $4^{c}$ \\
\hline ABCB1b & $0.1^{c}$ & $0.01^{c}$ & $0.01^{c}$ & $0.1^{c}$ & $1^{c}$ & $0.01^{c}$ & $0.01^{c}$ & $0.1^{c}$ & $2^{c}$ & $2^{b}$ & $2^{c}$ & $2^{c}$ \\
\hline FXR & $1^{c}$ & $0.1^{c}$ & NS & $1^{c}$ & $0.1^{\mathrm{b}}$ & NS & NS & NS & $2^{c}$ & NS & NS & NS \\
\hline PXR & $10^{\mathrm{b}}$ & NS & $0.1^{\mathrm{c}}$ & $1^{c}$ & $1^{\mathrm{b}}$ & $0.1^{\mathrm{b}}$ & $0.1^{\mathrm{b}}$ & $0.1^{\mathrm{c}}$ & NS & $2^{b}$ & $2^{c}$ & $2^{c}$ \\
\hline CAR & $1^{c}$ & $1^{c}$ & $10^{c}$ & $1^{c}$ & $1^{\mathrm{c}}$ & $0.1^{\mathrm{b}}$ & $0.1^{c}$ & $0.1^{\mathrm{c}}$ & $2^{b}$ & $4^{b}$ & $2^{c}$ & $2^{c}$ \\
\hline
\end{tabular}

mary hepatocytes (Figure 4F). With the notable exception of CYP2B2 in Iec-6 cells (Figure 4H), all CYPs were significantly induced in H411E cells (Figure 4G), Iec-6 cells (Figure 4H) and primary hepatocytes (Figure 4i) by PB. Finally, RIF had a potent effect on CYP3A1, CYP3A2, and CYP3A9 in all three cell types (Figure $4 \mathrm{~J}, 4 \mathrm{~K}$, and $4 \mathrm{~L}$ ). This effect occurred at lower concentration in Iec-6 (Figure $4 \mathrm{~K}$ ), requiring only $0.1 \mu \mathrm{mol} / \mathrm{L}$ RIF to elicit a significant effect.

Induction of $A B C B 1 a, A B C B 1 b, A B C C 1$, and $A B C C 2$ mRNA in H411E, lec-6, and primary hepatocytes

The impact of CDCA, PCN, PB, and RIF on the expression of rat transporters can be seen in Figure 5. With the exception of ABCC1 in lec-6 cells (Figure 5B), CDCA significantly upregulated all transporters in all three cell types (Figures 5A, 5B, and 5C). PCN significantly induced all transporters in H411E and primary hepatocytes (Figure 5f). ABCB1a, ABCB1b, and ABCC1 were also significantly upregulated in lec-6 (Figure 5E) when incubated with PCN. However, there was no significant induction of $\mathrm{ABCC} 2$ in Iec-6 below toxic concentrations (Figure $5 \mathrm{E}$ ). For $\mathrm{PB}$, there was a significant increase observed for mRNA expression of ABCB1a, ABCB1b, and ABCC2 in H411E (Figure 5G) and Iec-6 (Figure 5H) cells and all transporters in primary hepatocytes. However, PB did not elicit a significant effect on $A B C C 1$ in H411E or Iec-6 below toxic concentrations. RIF had a potent effect on all four transporters in all three cell lines (Figure 5J, 5K, and 5L). However, this effect was more marked with respect to magnitude of fold change for transporters in H411E (Figure 5J), significantly for ABCB1a compared to ABCB1b, ABCC1, and ABCC2.

Induction of CYP2B2, CYP3A1, CYP3A2, CYP3A9, АВCB1a/b, $A B C C 1$, and $A B C C 2$ protein in $\mathrm{H} 411 \mathrm{E}$ and lec- 6 cells

The effects of CDCA, PCN, PB, and RIF on protein expres- sion of CYP2B2, CYP3A1, CYP3A2, ABCB1a/b, ABCC1, and $\mathrm{ABCC} 2$ in H411E and Iec-6 is shown in Figure 6. CDCA significantly upregulated CYP2B2, CYP3A1, ABCB1a/b, ABCC1, and $\mathrm{ABCC} 2$ in $\mathrm{H} 411 \mathrm{E}$ and $\mathrm{CYP} 2 \mathrm{~B} 2, \mathrm{CYP} 3 \mathrm{~A} 1$, and $\mathrm{ABCC} 2$ in Iec- 6 cells. With the exception of ABCC1 and ABCC2 in Iec-6, PCN significantly upregulated all proteins in both H411E and Iec-6. PB upregulated CYP2B2, CYP3A2, CYP3A9, ABCB1a/b, ABCC1, and ABCC2 in H411E cells and CYP3A9 and $A B C B 1 a / b$ in Iec-6. RIF increased protein expression of CYP3A1, CYP3A2, ABCC1, and ABCC2 in H411E cells and CYP3A2, CYP3A9, ABCB1a/b, and ABCC2 in lec-6.

\section{Relationship between mRNA and protein expression}

The relationship between mRNA induction and protein expression for H411e and Iec- 6 can be seen in Figure 7 and Figure 8 respectively. In order to assess the relationship between mRNA induction and protein expression, $1 \mu \mathrm{mol} / \mathrm{L}$ mRNA data for each transcript were plotted against the corresponding protein data. Correlations for ABCB1a and ABCB1b were collated as no primary antibodies were available to differentiate the individual proteins. In H411E, a significant logarithmic correlation was observed for mRNA and protein for CYP2B2, CYP3A1, CYP3A2, ABCB1a/b, ABCC1, and ABCC2. For Iec-6 cells, significant logarithmic relationships were observed for CYP2B2, CYP3A2, CYP3A9, ABCB1a/b, and ABCC2. Interestingly, the relationship between mRNA and protein expression was linear for CYP3A1.

\section{Discussion}

There are clear limitations associated with the use of rodent systems when extrapolating to human. For example, species differences often make it difficult to extrapolate rodent observations directly ${ }^{[34-36]}$ and conventional reporter based assays demonstrate that species differences are apparent for 

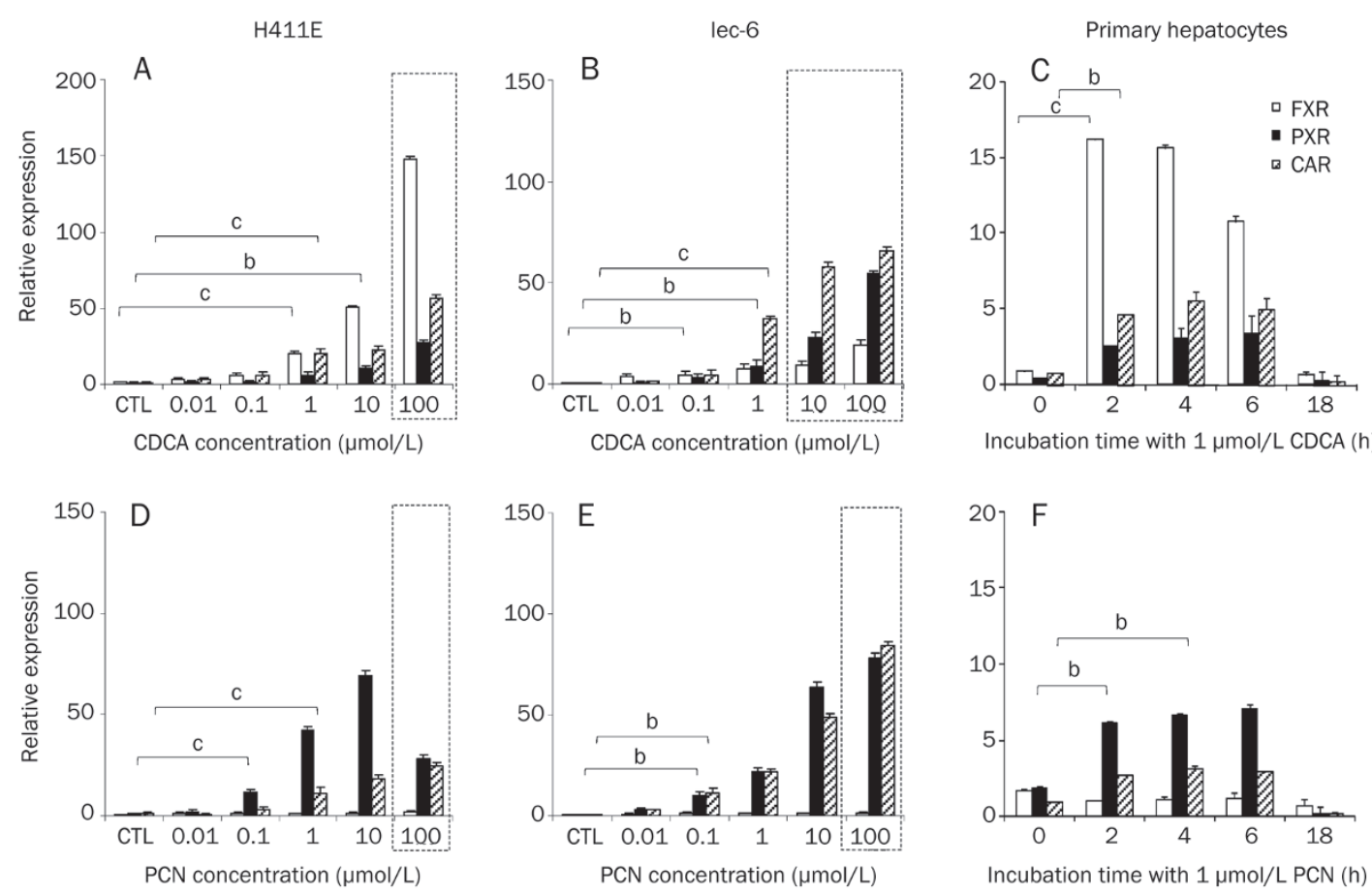

Incubation time with $1 \mu \mathrm{mol} / \mathrm{L} \mathrm{CDCA}(\mathrm{h})$
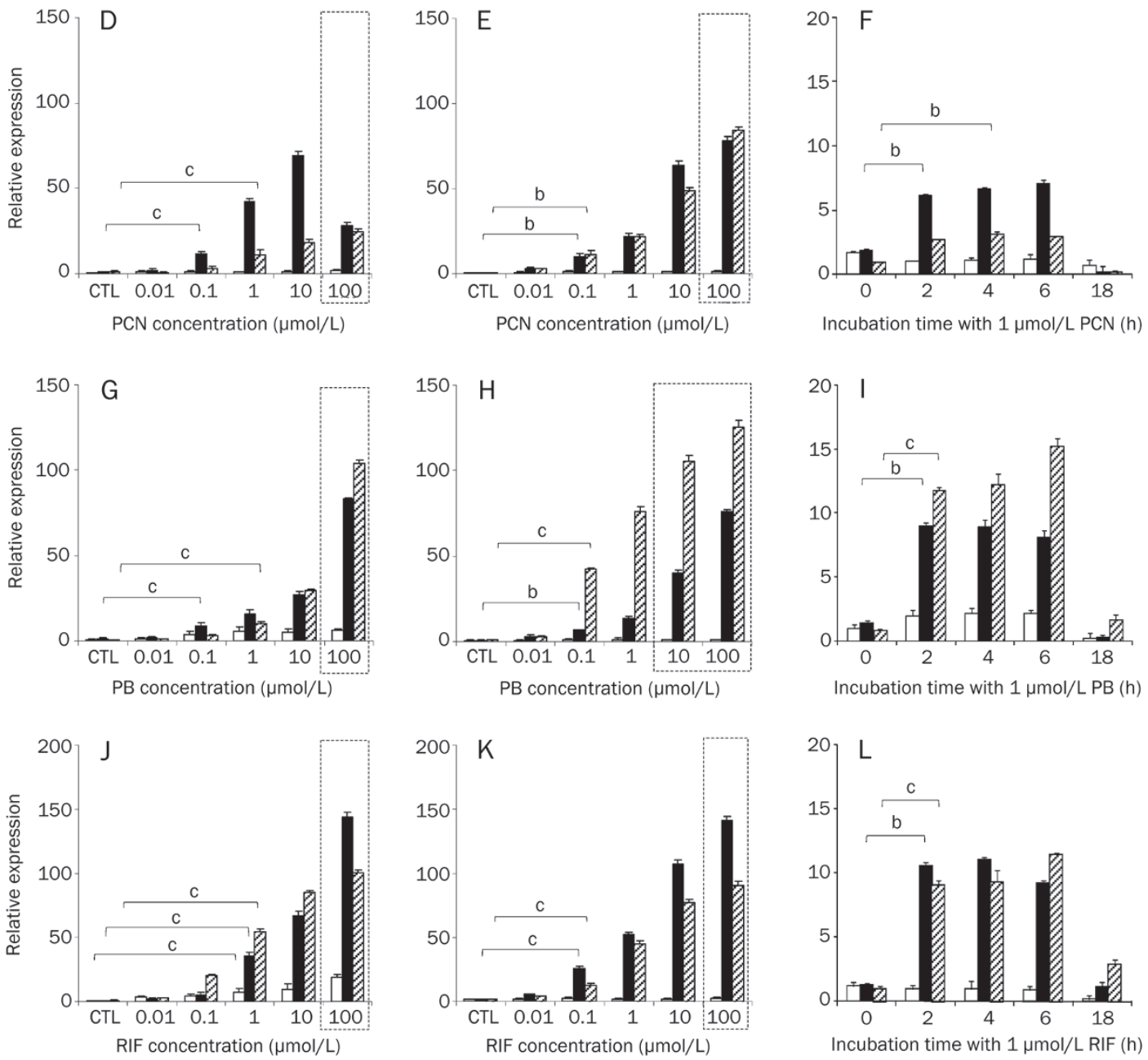

Incubation time with $1 \mu \mathrm{mol} / \mathrm{L}$ PB (h)

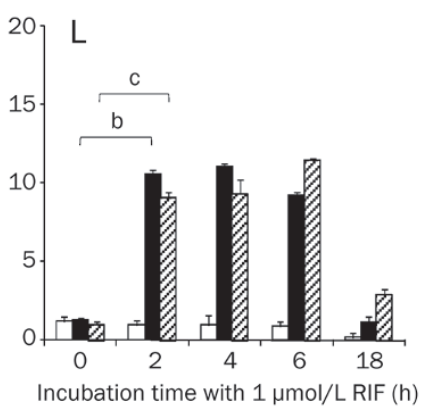

Figure 3. Impact of typical activators on nuclear receptors. Effect of chenodeoxycholic acid (CDCA) (A-C), pregnenolone 16 $\alpha-c a r b o n i t r i l e ~(P C N)$ (D-F), phenobarbital (PB) (G-I) and rifampicin (RIF) $(\mathrm{J}-\mathrm{I})$ in H411E, lec-6 and primary hepatocytes. Data are mean \pm SD of four experiments conducted in duplicate. In cell lines, concentration dependency was investigated, whereas, in primary cells, time dependency was assessed at $1 \mu \mathrm{mol} / \mathrm{L}$ of each compound. Dotted lines indicate concentrations at which toxicity was observed following 5-day incubations with drug. For clarity, statistical analyses are given only for the lowest concentration at which a significant difference was observed: ${ }^{b} P<0.05,{ }^{c} P<0.01$.

some ligands for $\mathrm{PXR}^{[37]}$. Importantly, $\mathrm{PCN}$ has been shown to activate rodent PXR but not human and the converse true for $\mathrm{RIF}^{[17]}$. However, other studies have reported that RIF treatment of rat hepatocytes increases CYP3A protein and PCN induces CYP3A mRNA in 50\% of human cultures ${ }^{[38]}$ and has also been shown to activate PXR in some human systems ${ }^{[39]}$.
Cell lines have been reported to express decreased levels of certain transporters and CYP isoforms compared to primary cells ${ }^{[40,41]}$. Previously, we have reported instability and variability of expression of some CYPs, transporters and nuclear receptors in the human hepatic (HepG2) and intestinal (Caco-2) cells over time ${ }^{[1]}$. Therefore, we conducted an initial 

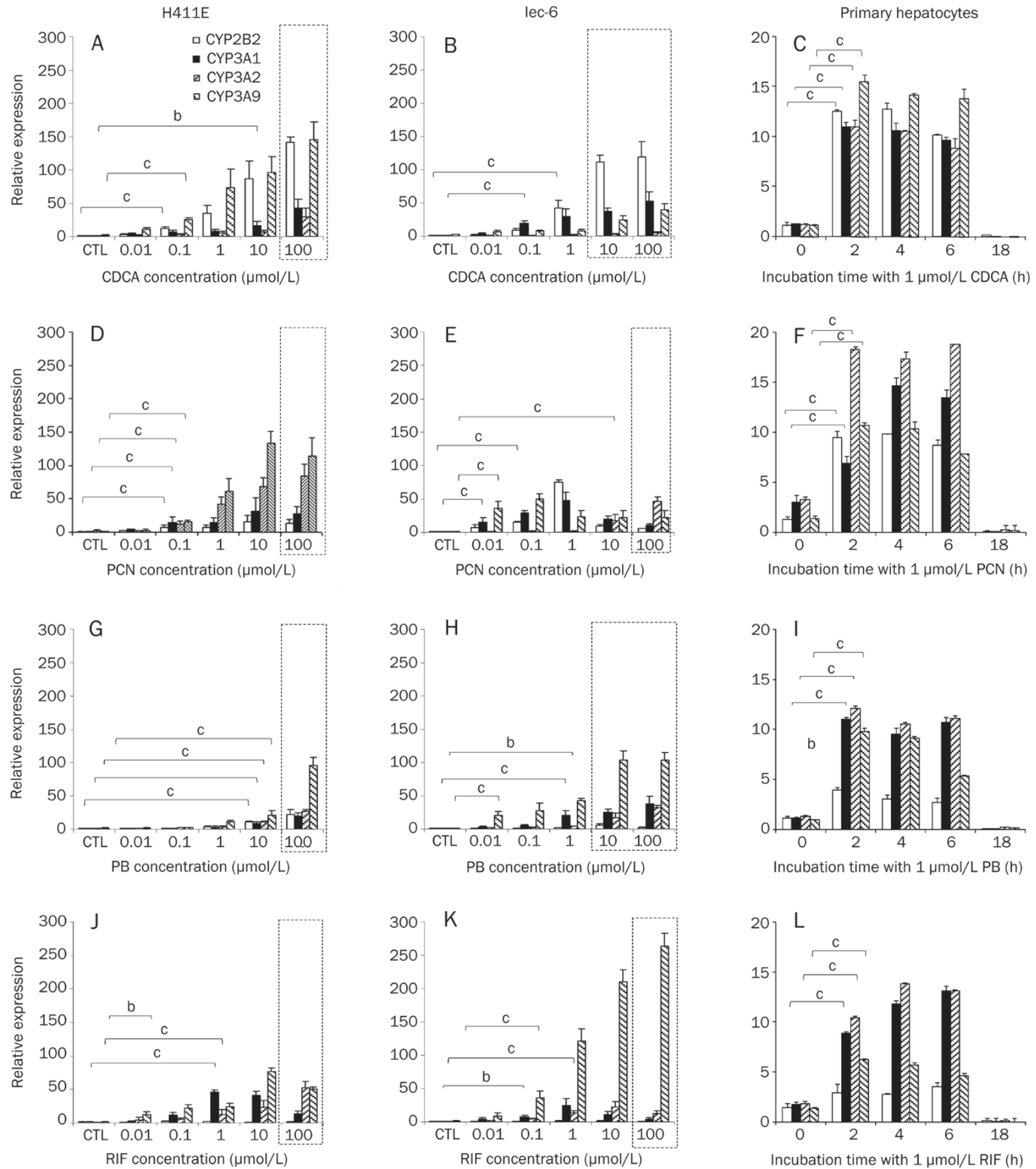

Figure 4. Impact of typical activators on CYP isoforms. Effect of chenodeoxycholic acid (CDCA) (A-C), pregnenolone 16 $\alpha-c a r b o n i t r i l e ~(P C N) ~(D-F)$, phenobarbital (PB) (G-I) and rifampicin (RIF) (J-I) in H411E, lec-6 and primary hepatocytes. Data are mean \pm SD of four experiments conducted in duplicate. In cell lines, concentration dependency was investigated, whereas, in primary cells, time dependency was assessed at $1 \mu \mathrm{mol} / \mathrm{L}$ of each compound. Dotted lines indicate concentrations at which toxicity was observed following 5-day incubations with drug. For clarity, statistical analyses are given only for the lowest concentration at which a significant difference was observed: ${ }^{\mathrm{b}} P<0.05,{ }^{\mathrm{c}} \mathrm{P}<0.01$.

screen of the studied transcripts in H411E and Iec-6 in order to assess basal levels of expression and stability of transcripts. However, unlike HepG2 and Caco-2, all CYPs, transporters and nuclear receptors were found to be stable in the rodent cell lines used here.

Isolated primary hepatocytes can be used in suspension or they can be cultured ${ }^{[42-44]}$. In suspension they exhibit metabolic activity for a period of 4 to $6 h^{[45]}$, thus remaining useful for the study of drug metabolism or toxicity ${ }^{[46]}$. However, gene expression changes taking place in primary hepatocyte cultures over time $(0-18 \mathrm{~h})$ in the absence of treatment were assessed and were consistent with previous studies involving 

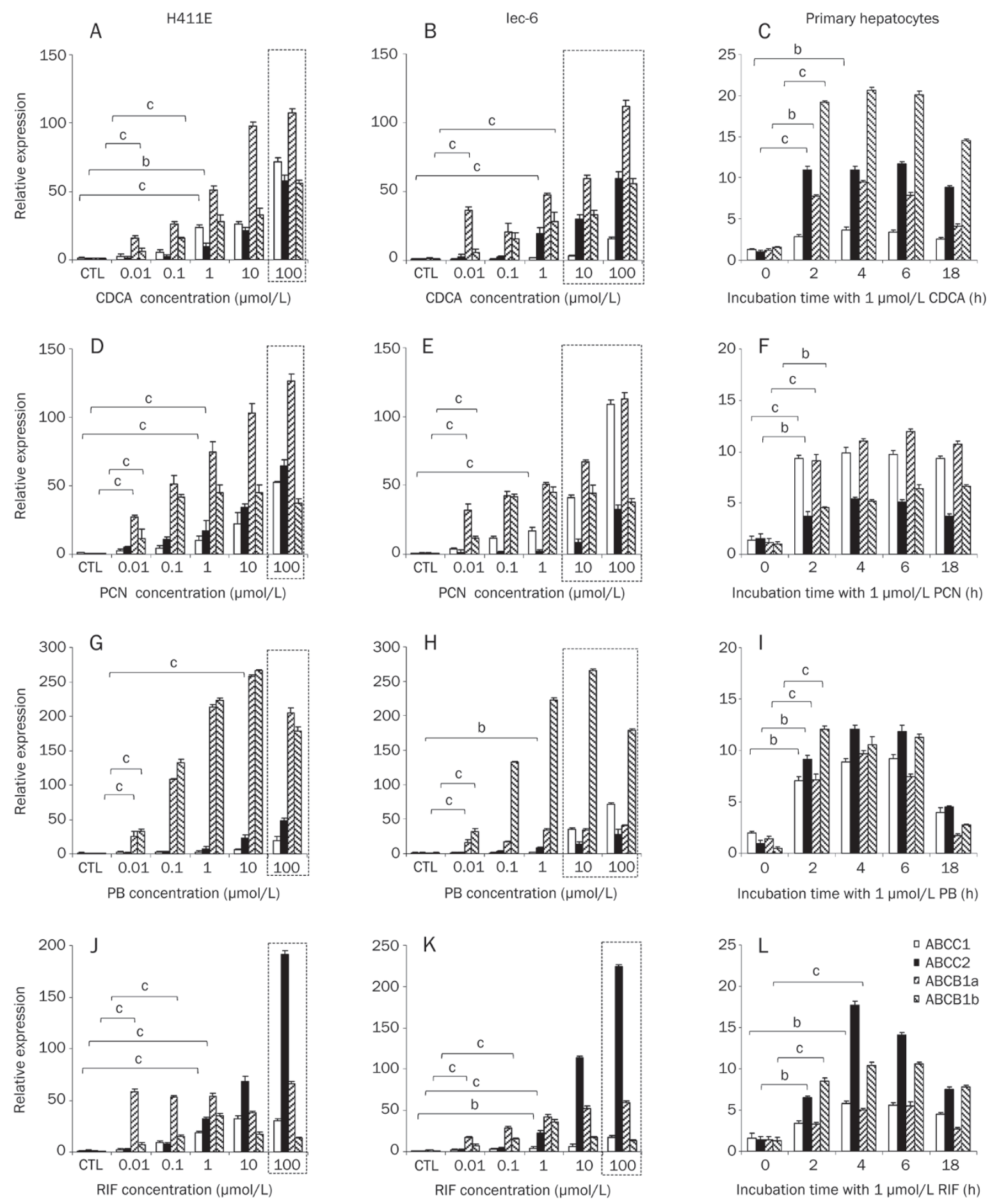

Figure 5. Impact of typical activators on transporters. Effect of chenodeoxycholic acid (CDCA) (A-C), pregnenolone 16 $\alpha-c a r b o n i t r i l e ~(P C N) ~(D-F)$, phenobarbital (PB) (G-I) and rifampicin (RIF) (J-I) in H411E, lec-6 and primary hepatocytes. Data are mean \pm SD of four experiments conducted in duplicate. In cell lines, concentration dependency was investigated, whereas, in primary cells, time dependency was assessed at $1 \mu \mathrm{mol} / \mathrm{L}$ of each compound. Dotted lines indicate concentrations at which toxicity was observed following 5-day incubations with drug. For clarity, statistical analyses are given only for the lowest concentration at which a significant difference was observed: ${ }^{\mathrm{b}} P<0.05,{ }^{\mathrm{c}} P<0.01$.

hepatocytes in pure cultures ${ }^{[47,48]}$.

The glucocorticoid DEX, is a widely used component in culture media and has been reported to exert a protective role on cell survival, prolonging cell viability, inhibiting the develop- ment of an apoptotic morphology, and stabilising expression of procaspase- 3 in both human and rat hepatocytes ${ }^{[49]}$. However, DEX is a known inducer of the human PXR target gene CYP3A4 and has also been shown to affect p-glycoprotein 


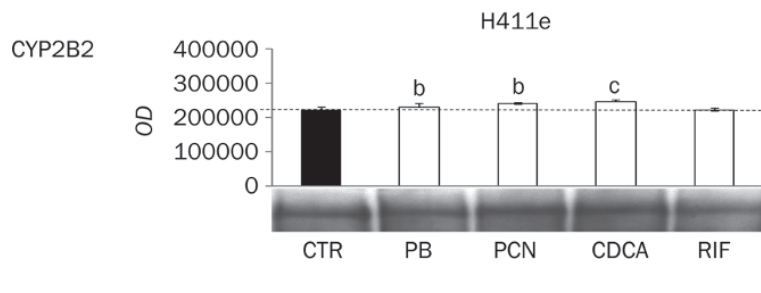

CYP3A1

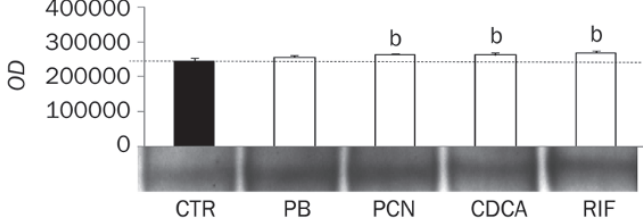

CYP3A2

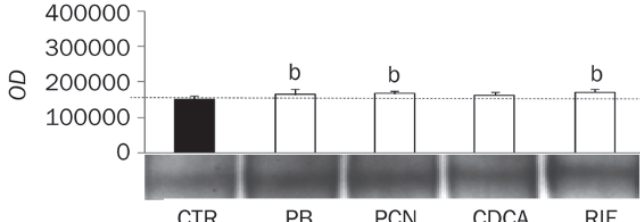

CYP3A9

400000

- 200000

100000

0

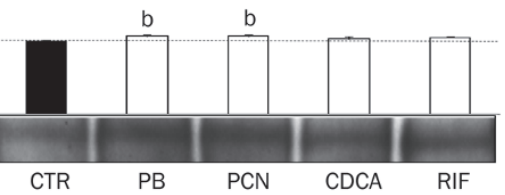

ABCB1a/b

$$
\begin{array}{r}
500000 \\
400000 \\
300000 \\
200000 \\
100000
\end{array}
$$

0
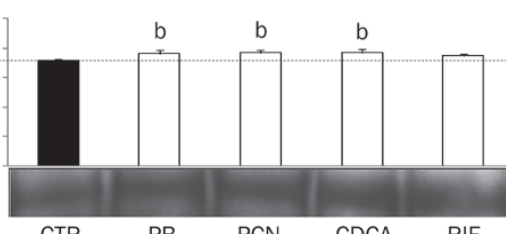

ABCC1

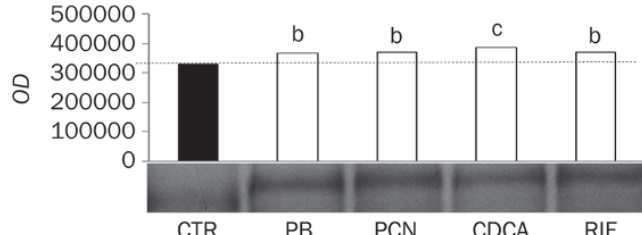

ABCC2

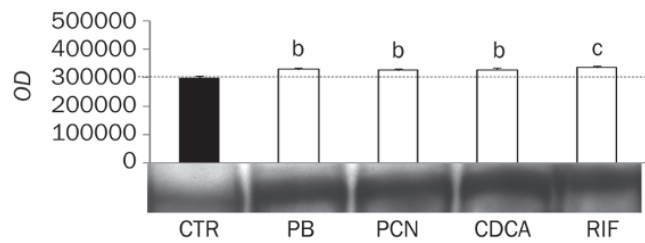

$\beta$-actin

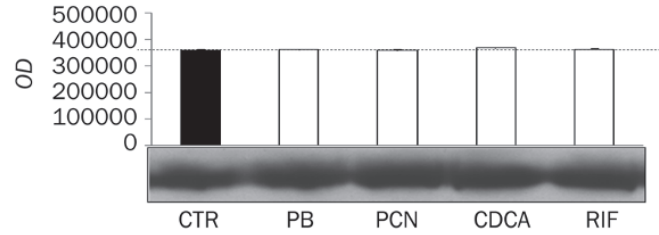

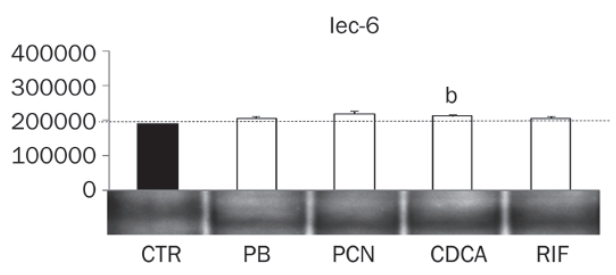

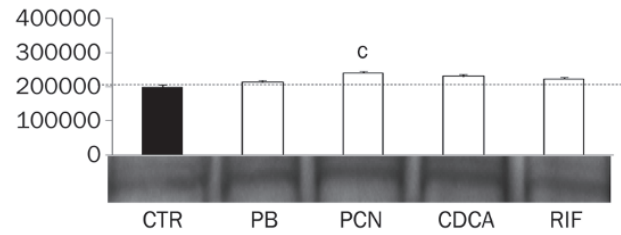

400000

300000

200000

100000

0

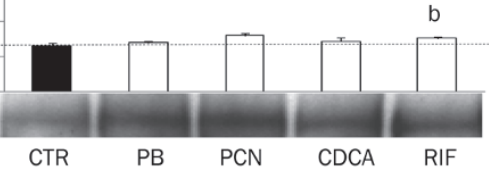

400000

300000

200000

100000
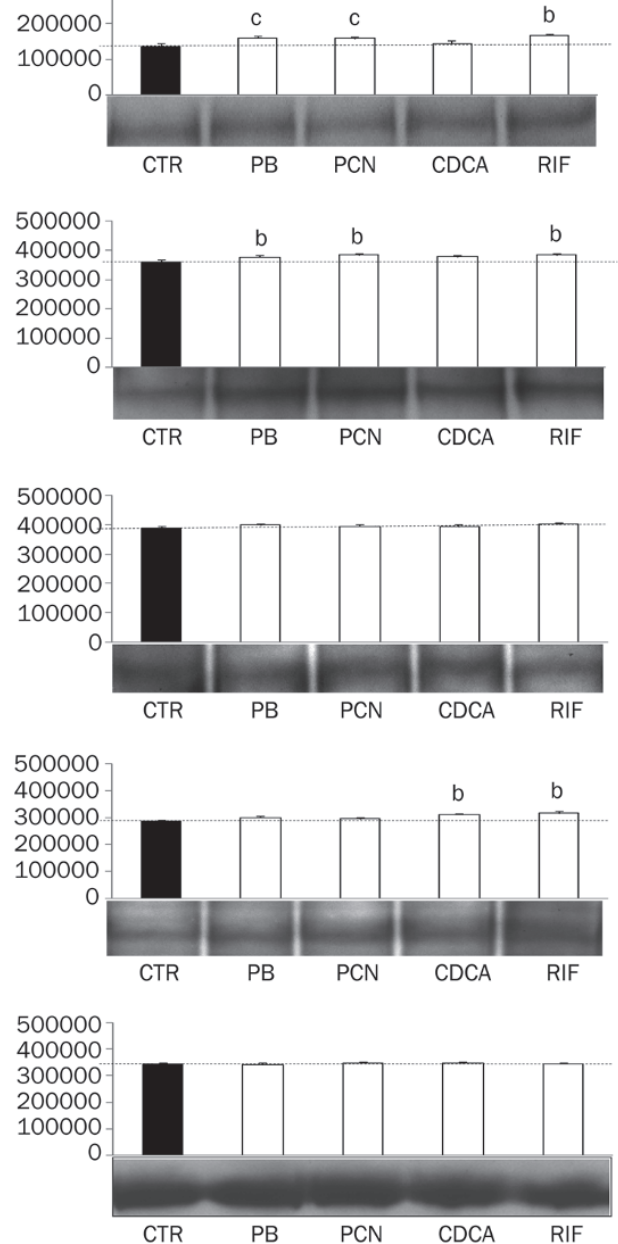

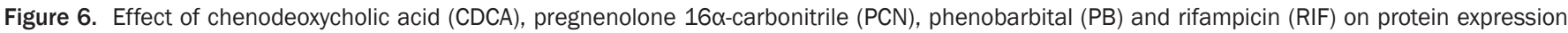

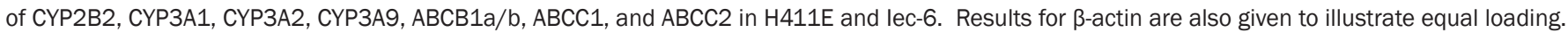

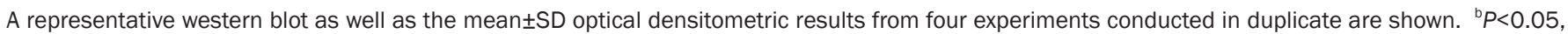
${ }^{\mathrm{c}} \mathrm{P}<0.01$. 

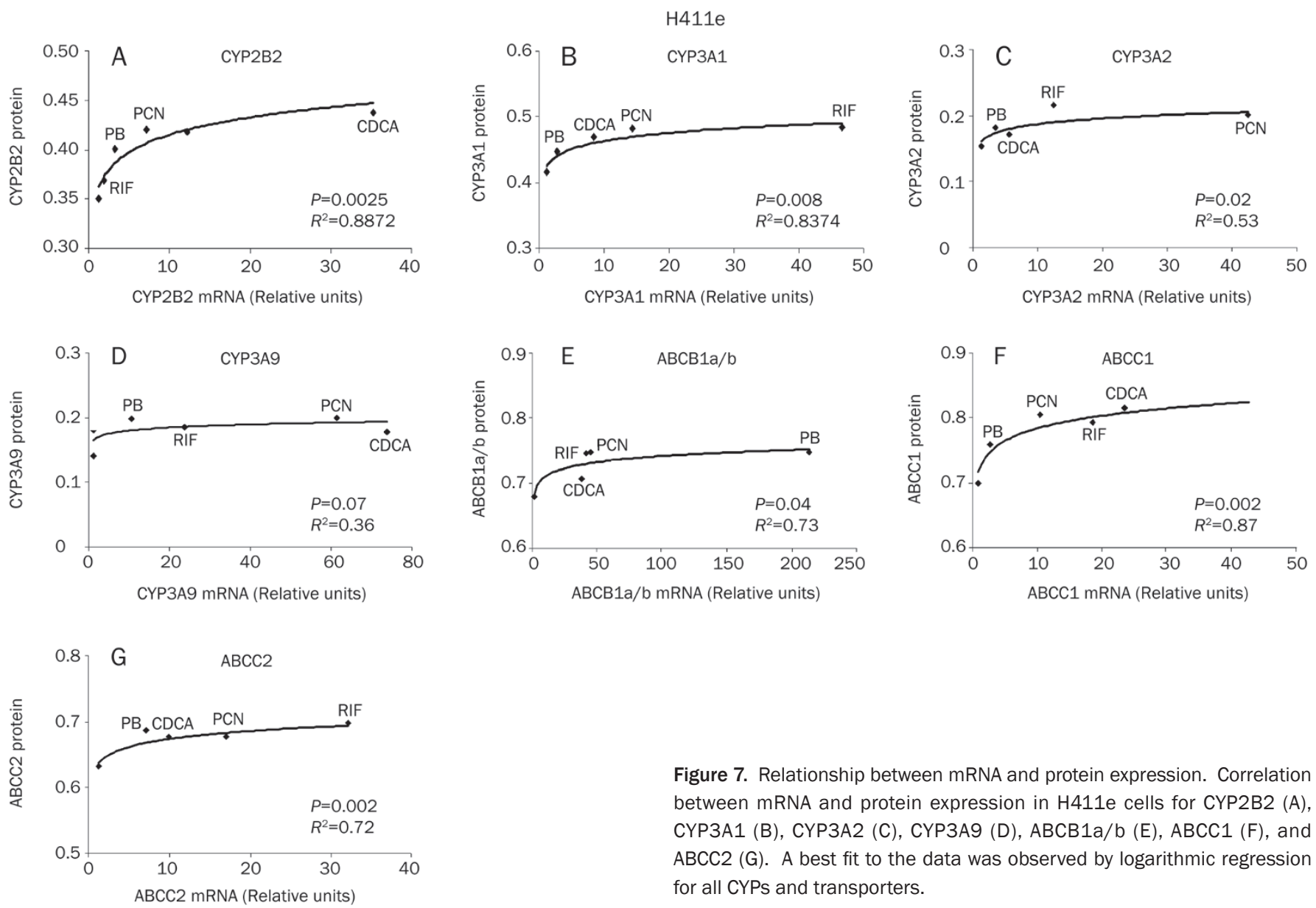

Figure 7. Relationship between mRNA and protein expression. Correlation between mRNA and protein expression in H411e cells for CYP2B2 (A), CYP3A1 (B), CYP3A2 (C), CYP3A9 (D), ABCB1a/b (E), ABCC1 (F), and $A B C C 2(G)$. A best fit to the data was observed by logarithmic regression for all CYPs and transporters.

(P-gp) activity ${ }^{[50]}$ and expression in primary rat hepatocytes ${ }^{[51]}$. In addition, DEX is believed to be a prerequisite for PCN inducible genes in rodent hepatocytes ${ }^{[52]}$. Previously we have shown that PCN upregulates expression of human CYP3A4, ABCB1 and PXR mRNA and inclusion of DEX as a media supplement resulted in a loss of ability to detect induction by PCN in human cells ${ }^{[1]}$. Generally, data presented herein show DEX had a similar effect in rat cells, where DEX significantly upregulated CYP3A9, ABCB1a, ABCB1b, and PXR. This is in broad agreement with similar observations in rat liver slices ${ }^{[53]}$. Furthermore, these data indicate a maximal response to PCN. Therefore, the addition of DEX increases the relative baseline but, as the maximum is fixed, a reduction in the potential effect is observed. This may allow competition in order to enable the biological system to prevent over-activation. Interestingly, a previous study indicated that the effects of DEX and PCN on rodent PXR target gene CYP3A1 were partially dependent upon the order these compounds were administered ${ }^{[54]}$.

The mechanisms controlling this PCN/DEX response currently remain unclear. However, previously it has been shown that sub-micromolar concentrations of PCN activate rodent $\mathrm{PXR}^{[55]}$ but antagonise the glucocorticoid receptor (GR). Furthermore, activation of GR by DEX increases PXR expression and increases CYP3A1, whereas PCN activates PXR directly ${ }^{[54]}$. In addition, the proposed existence of a cascade of signal transmission: GR-[PXR/CAR]-metabolising enzymestransporters ${ }^{[56]}$ may explain the xenobiotic-mediated induction of CYP2B and CYP3A by prototypical activators of PXR and CAR in the presence of DEX ${ }^{[57-60]}$. Importantly, this cascade would imply processes affecting the transcriptional activity of GR would subsequently affect the expression of PXR, CAR and FXR, and thus the expression of their target genes ${ }^{[57]}$. Therefore, it is not possible to assume that the induction reported here is necessarily due to discrete activation of individual nuclear receptors. However, the issues involving the DEX effect, coupled with attempts to facilitate comparisons with our human data ${ }^{[1]}$ led us not to include it as a supplement in subsequent experiments.

Significant induction of mRNA and protein of many transcripts in cell lines H411E and Iec- 6 and primary hepatocytes in response to the nuclear receptor ligands were observed. Interestingly, for some of the genes investigated, a change in mRNA was observed with no corresponding change in protein and vice-versa. For example, mRNA was induced with no increase in protein for CYP3A9 by CDCA in H411e and CYP3A1 by PB in Iec-6, whereas increases in protein for ABCC1 by PB in H411e and ABCC2 by CDCA in Iec- 6 with no corresponding increase in mRNA. However, recent work util- 

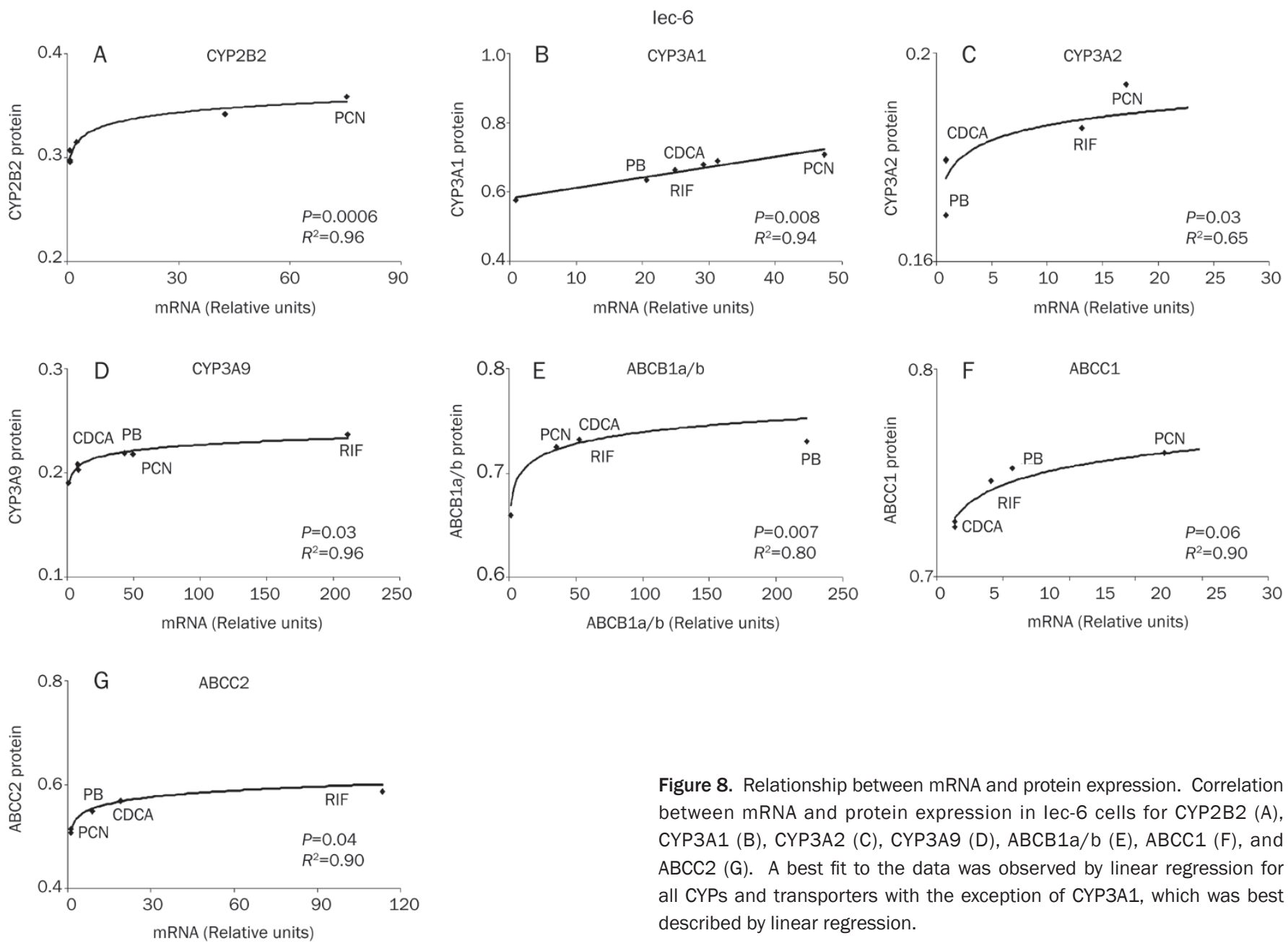

Figure 8. Relationship between mRNA and protein expression. Correlation between mRNA and protein expression in lec-6 cells for CYP2B2 (A), CYP3A1 (B), CYP3A2 (C), CYP3A9 (D), ABCB1a/b (E), ABCC1 (F), and $A B C C 2(G)$. A best fit to the data was observed by linear regression for all CYPs and transporters with the exception of CYP3A1, which was best described by linear regression.

ising microarray analysis has indicated that total mRNA levels do not always reflect protein levels ${ }^{[61]}$. For example, a study by Ideker et al, 2001, calculated an overall Pearson correlation coefficient between mRNA and protein expression of 0.61 , although no change in protein expression was observed for almost $80 \%$ of genes reported as having a significant change in mRNA, indicating that a complex relationship exists between mRNA and protein expression. This work supporting data from a previous study ${ }^{[2]}$ where they observed a poor correlation between mRNA and protein for all but the most abundant proteins examined. Some similarities and important differences were seen in the profiles of induction in H411E versus Iec-6 cells. However, our data are in broad agreement with previous studies conducted in rat cells incubated with $\mathrm{PB}^{[63,64]}$, $\mathrm{PCN}^{[65,66]}$, and $\mathrm{RIF}{ }^{[38]}$. Where differences were observed, it is unclear whether this is due to inherent differences associated with specific tissue type (hepatic or intestinal) or whether they are due partly to the dedifferentiation process that occurs when generating and passaging continuously dividing cell systems. Specifically, because drug metabolism is a hallmark of highly differentiated, nondividing hepatocytes ${ }^{[67]}$.

For rat primary hepatocytes, our study conflicts with pre- vious studies which indicated that RIF had no effect on rat $\mathrm{PXR}^{[17]}$. However, these investigators included DEX as a culture supplement and our observations that rat CYP3As are inducible by RIF is in agreement with another study ${ }^{[68]}$. Taken together these observations reinforce the probability that culturing conditions, including commonly used culture supplements i.e. antibiotics, FBS concentration, and DEX, play a major role in the variability of results between laboratories.

Several interesting observations have emerged from this study. Of note, all compounds were potent inducers of $A B C B 1 a$ and $A B C B 1 b, A B C C 1$ and $A B C C 2$. Importantly, CDCA and RIF were more potent with respect to magnitude of fold change and drug concentration for ABCB1a compared to $\mathrm{ABCB} 1 \mathrm{~b}$, generally requiring the lowest concentration $(0.01$ $\mu \mathrm{mol} / \mathrm{L})$ to elicit a significant effect. This response is consistent with observations by ${ }^{[69]}$, who reported preferential induction of $A B C B 1$ a versus $A B C B 1 b$. While it is difficult to directly link specific regulation of $A B C B 1 a$ and $A B C B 1 b$ to $P X R$ and $C A R$ and thus their relative contribution, from data presented herein. However, PCN and PB were more potent inducers of PXR than CAR in H411E and primary hepatocytes than for CAR in Iec-6 intestinal cells. Indeed, these observations are 
similar to a previous study ${ }^{[16]}$ where they noted CAR had an additional effect on ABCB1a. Also of note, ABCC2 mRNA levels were found to be markedly increased in primary rat hepatocytes exposed to all test compounds. In addition, a previous study also observed that ABCC2 was up-regulated at higher concentrations of $\mathrm{PB}$ than that needed for induction of rat CYP2B and CYP3A genes ${ }^{[70]}$. This confirms the PB-mediated up-regulation of $A B C C 2^{[71]}$ and suggests that ABCC2 and CYPs are differentially regulated in response to $\mathrm{PB}$.

CDCA had a potent effect on transporters, including $\mathrm{ABCC} 2$, in this study. Interestingly, it has also been reported that activation of FXR by CDCA is dependent upon the species examined, with CDCA having both an increased potency and magnitude of induction through human FXR than rodent $\mathrm{FXR}^{[72]}$. This is in partial agreement with this study and our previous observations ${ }^{[1]}$ where we found the effect of CDCA on FXR more potent for HepG2 than for H411E and a higher magnitude of induction for Caco-2 than for Iec-6. Furthermore, in both studies, human and rodent, we observed that CDCA was the only compound to significantly induce FXR mRNA.

\section{Conclusion}

In summary, induction of key transcriptional regulators PXR, CAR, and FXR by paradigm nuclear receptor ligands PB, PCN, RIF and CDCA in rat hepatic (H411E) and intestinal (Iec-6) cell lines and primary hepatocytes has been shown. In addition, a consequence of their induction is a corresponding induction of their target genes. Importantly, purported species specific PXR activators RIF (human PXR) and PCN (rodent PXR) showed comparable induction profiles of PXR and PXR target genes in all cells in the absence of DEX. Therefore, although species differences in activation of nuclear receptors are clearly evident, a similar spectrum of induction of target genes occurs in human and rat cells.

\section{Acknowledgements}

This work was funded by AstraZeneca Charnwood.

\section{Author contribution}

Philip MARTIN designed and performed all research experiments, collated all data and wrote the manuscript; Dominic WILLIAMS isolated fresh rat primary hepatocytes; Robert RILEY assisted with protein binding experiments and review of manuscript. Paul THOMPSON assisted with immunoblots and review of manuscript. David BACK assisted with writing and reviewing manuscript. Andrew OWEN performed statistical analysis for the relationship between mRNA and protein and writing manuscript.

\section{References}

1 Martin P, Riley R, Back DJ, Owen A. Comparison of the induction profile for drug disposition proteins by typical nuclear receptor activators in human hepatic and intestinal cells. $\mathrm{Br} J$ Pharmacol 2008; 153: 805-19.

2 Kirita S, Matsubara T. cDNA cloning and characterization of a novel member of steroid-induced cytochrome P450 3A in rats. Arch Biochem Biophys 1993; 307: 253-8.

3 Komori M, Oda Y. A major glucocorticoid-inducible P450 in rat liver is not P450 3A1. J Biochem 1994; 116: 114-20.

4 Gonzalez FJ, Song BJ, Hardwick JP. Pregnenolone 16 alphacarbonitrile-inducible P-450 gene family: gene conversion and differential regulation. Mol Cell Biol 1986; 6: 2969-76.

5 Xue L, Zgoda VG, Arison B, Almira Correia M. Structure-function relationships of rat liver CYP3A9 to its human liver orthologs: sitedirected active site mutagenesis to a progesterone dihydroxylase. Arch Biochem Biophys 2003; 409: 113-26.

6 Strotkamp D, Roos PH, Hanstein WG. A novel CYP3 gene from female rats. Biochim Biophys Acta 1995; 1260: 341-4.

7 Nagata K, Murayama N, Miyata M, Shimada M, Urahashi A, Yamazoe $\mathrm{Y}$, et al. Isolation and characterization of a new rat P450 (CYP3A18) cDNA encoding P450(6)beta-2 catalyzing testosterone 6 beta- and 16 alpha-hydroxylations. Pharmacogenetics 1996; 6: 103-11.

8 Deng Y, Bi HC, Zhao LZ, He F, Liu YQ, Yu JJ, et al. Induction of cytochrome P450s by terpene trilactones and flavonoids of the Ginkgo biloba extract EGb 761 in rats. Xenobiotica 2008; 38: 465-81.

9 Garcia MC, Ma D, Dicioccio AT, Cali J. The use of a high-throughput luminescent method to assess CYP3A enzyme induction in cultured rat hepatocytes. In Vitro Cell Dev Biol Anim 2008; 44: 129-34.

10 Hartley DP, Dai X, He YD, Carlini EJ, Wang B, Huskey SE, et al. Activators of the rat pregnane $X$ receptor differentially modulate hepatic and intestinal gene expression. Mol Pharmacol 2004; 65: 1159-71.

11 Audet-Walsh E, Lachaud AA, Anderson A. The CYP2B2 5' flank contains a complex glucocorticoid response unit. Biochem Pharmacol 2008; 76: 1298-306.

12 Shinohara T, Taura K, Imamura T, Yamada H, Oguri K. Induction of rat hepatic cytochrome P450 2B subfamily by azidophenobarbital, as a possible photoaffinity probe for the putative phenobarbital receptor: comparative study with modified phenobarbitals with different functional groups. Drug Metab Dispos 1997; 25: 1442-6.

13 Stoltz C, Vachon MH, Trottier E, Dubois S, Paquet Y, Anderson A. The CYP2B2 phenobarbital response unit contains an accessory factor element and a putative glucocorticoid response element essential for conferring maximal phenobarbital responsiveness. J Biol Chem 1998; 273: 8528-36.

14 Roberge C, Beaudet MJ, Anderson A. GABA(A)/central benzodiazepine receptor and peripheral benzodiazepine receptor ligands as inducers of phenobarbital-inducible CYP2B and CYP3A. Biochem Pharmacol 2004; 68: 1383-9.

15 Waxman DJ, Azaroff L. Phenobarbital induction of cytochrome P-450 gene expression. Biochem J 1992; 281 (Pt 3): 577-92.

16 Maglich JM, Stoltz CM, Goodwin B, Hawkins-Brown D, Moore JT, Kliewer SA. Nuclear pregnane X receptor and constitutive androstane receptor regulate overlapping but distinct sets of genes involved in xenobiotic detoxification. Mol Pharmacol 2002; 62: 638-46.

17 Jones SA, Moore LB, Shenk JL, Wisely GB, Hamilton GA, McKee DD, et al. The pregnane $X$ receptor: a promiscuous xenobiotic receptor that has diverged during evolution. Mol Endocrinol 2000; 14: 27-39.

18 Quattrochi LC, Guzelian PS. CYP3A regulation: from pharmacology to nuclear receptors. Drug Metab Dispos 2001; 29: 615-22.

19 Modica S, Moschetta A. Nuclear bile acid receptor FXR as pharmacological target: are we there yet? FEBS Lett 2006; 580: 5492-9.

20 Wang YD, Chen WD, Moore DD, Huang W. FXR: a metabolic regulator and cell protector. Cell Res 2008; 18: 1087-95.

21 Sonoda J, Pei L, Evans RM. Nuclear receptors: decoding metabolic disease. FEBS Lett 2008; 582: 2-9. 
22 Xie W, Radominska-Pandya A, Shi Y, Simon CM, Nelson MC, Ong ES, et al. An essential role for nuclear receptors SXR/PXR in detoxification of cholestatic bile acids. Proc Natl Acad Sci USA 2001; 98: 3375-80.

23 Stedman CA, Liddle C, Coulter SA, Sonoda J, Alvarez JG, Moore DD, et al. Nuclear receptors constitutive androstane receptor and pregnane $X$ receptor ameliorate cholestatic liver injury. Proc Natl Acad Sci USA 2005; 102: 2063-8.

24 Echchgadda I, Song CS, Roy AK, Chatterjee B. Dehydroepiandrosterone sulfotransferase is a target for transcriptional induction by the vitamin D receptor. Mol Pharmacol 2004; 65: 720-9.

25 Kast HR, Goodwin B, Tarr PT, Jones SA, Anisfeld AM, Stoltz CM, et al. Regulation of multidrug resistance-associated protein 2 (ABCC2) by the nuclear receptors pregnane $\mathrm{X}$ receptor, farnesoid $\mathrm{X}$-activated receptor, and constitutive androstane receptor. J Biol Chem 2002; 277: 2908-15.

26 Sambruy Y, Ferruzza S, Ranaldi G, De Angelis I. Intestinal cell culture models: applications in toxicology and pharmacology. Cell Biol Toxicol 2001; 17: 301-17.

27 Lin JH. CYP induction-mediated drug interactions: in vitro assessment and clinical implications. Pharm Res 2006; 23: 1089-116.

28 Loretz $\sqcup$, Li AP, Flye MW, Wilson AG. Optimization of cryopreservation procedures for rat and human hepatocytes. Xenobiotica 1989; 19 : 489-98.

29 Li AP, Lu C, Brent JA, Pham C, Fackett A, Ruegg CE, et al. Cryopreserved human hepatocytes: characterization of drug-metabolizing enzyme activities and applications in higher throughput screening assays for hepatotoxicity, metabolic stability, and drug-drug interaction potential. Chem Biol Interact 1999; 121: 17-35.

30 Owen A, Chandler B, Back DJ, Khoo SH. Expression of pregnane$X$-receptor transcript in peripheral blood mononuclear cells and correlation with MDR1 mRNA. Antivir Ther 2004; 9: 819-21.

31 Mosmann T. Rapid colorimetric assay for cellular growth and survival: application to proliferation and cytotoxicity assays. J Immunol Methods 1983; 65: 55-63.

32 Marshak D. Strategies for protein purification and characterization: A laboratory course manual. Plainview (NY): Cold Spring Harbor Laboratory Press; 1996.

33 Stoscheck CM. Quantitation of protein. Methods Enzymol 1990; 182: 50-68.

34 Bogaards JJ, Bertrand M, Jackson P, Oudshoorn MJ, Weaver RJ, van Bladeren PJ, et al. Determining the best animal model for human cytochrome P450 activities: a comparison of mouse, rat, rabbit, dog, micropig, monkey and man. Xenobiotica 2000; 30: 1131-52.

35 Barton HA, Pastoor TP, Baetcke K, Chambers JE, Diliberto J, Doerrer NG, et al. The acquisition and application of absorption, distribution, metabolism, and excretion (ADME) data in agricultural chemical safety assessments. Crit Rev Toxicol 2006; 36: 9-35.

36 Muruganandan S, Sinal CJ. Mice as clinically relevant models for the study of cytochrome P450-dependent metabolism. Clin Pharmacol Ther 2008; 83: 818-28.

37 Poso A, Honkakoski P. Ligand recognition by drug-activated nuclear receptors PXR and CAR: structural, site-directed mutagenesis and molecular modeling studies. Mini Rev Med Chem 2006; 6: 937-47.

38 Kocarek TA, Schuetz EG, Strom SC, Fisher RA, Guzelian PS. Comparative analysis of cytochrome P4503A induction in primary cultures of rat, rabbit, and human hepatocytes. Drug Metab Dispos 1995; 23 : 415-21.

39 El-Sankary W, Gibson GG, Ayrton A, Plant N. Use of a reporter gene assay to predict and rank the potency and efficacy of CYP3A4 inducers. Drug Metab Dispos 2001; 29: 1499-504.

40 Nakamura T, Sakaeda T, Ohmoto N, Tamura T, Aoyama N, Shirakawa
T, et al. Real-time quantitative polymerase chain reaction for MDR1, MRP1, MRP2, and CYP3A-mRNA levels in Caco-2 cell lines, human duodenal enterocytes, normal colorectal tissues, and colorectal adenocarcinomas. Drug Metab Dispos 2002; 30: 4-6.

41 Wilkening S, Stahl F, Bader A. Comparison of primary human hepatocytes and hepatoma cell line Hepg2 with regard to their biotransformation properties. Drug Metab Dispos 2003; 31: 1035-42.

42 Waring JF, Ciurlionis R, Jolly RA, Heindel M, Gagne G, Fagerland JA, et al. Isolated human hepatocytes in culture display markedly different gene expression patterns depending on attachment status. Toxicol In Vitro 2003; 17: 693-701.

43 Houle R, Raoul J, Levesque JF, Pang KS, Nicoll-Griffith DA, Silva JM. Retention of transporter activities in cryopreserved, isolated rat hepatocytes. Drug Metab Dispos 2003; 31: 447-51.

44 Sosef MN, Baust JM, Sugimachi K, Fowler A, Tompkins RG, Toner M. Cryopreservation of isolated primary rat hepatocytes: enhanced survival and long-term hepatospecific function. Ann Surg 2005; 241 : 125-33.

45 Cervenkova K, Belejova M, Vesely J, Chmela Z, Rypka M, Ulrichova $\mathrm{J}$, et al. Cell suspensions, cell cultures, and tissue slices-important metabolic in vitro systems. Biomed Pap Med Fac Univ Palacky Olomouc Czech Repub 2001; 145: 57-60.

46 Morel F, Langouet S, Maheo K, Guillouzo A. The use of primary hepatocyte cultures for the evaluation of chemoprotective agents. Cell Biol Toxicol 1997; 13: 323-9.

47 Tuschl G, Mueller SO. Effects of cell culture conditions on primary rat hepatocytes-cell morphology and differential gene expression. Toxicology 2006; 218: 205-15.

48 Paine AJ. The maintenance of cytochrome P-450 in rat hepatocyte culture: some applications of liver cell cultures to the study of drug metabolism, toxicity and the induction of the P-450 system. Chem Biol Interact 1990; 74: 1-31.

49 Bailly-Maitre B, de Sousa G, Boulukos K, Gugenheim J, Rahmani R. Dexamethasone inhibits spontaneous apoptosis in primary cultures of human and rat hepatocytes via $\mathrm{Bcl}-2$ and $\mathrm{Bcl}-\mathrm{x}_{\mathrm{L}}$ induction. Cell Death Differ 2001; 8: 279-88.

50 Chieli E, Santoni-Rugiu E, Cervelli F, Sabbatini A, Petrini M, Romiti $\mathrm{N}$, et al. Differential modulation of P-glycoprotein expression by dexamethasone and 3-methylcholanthrene in rat hepatocyte primary cultures. Carcinogenesis 1994; 15: 335-41.

51 Fardel O, Lecureur V, Guillouzo A. Regulation by dexamethasone of P-glycoprotein expression in cultured rat hepatocytes. FEBS Lett 1993; 327: 189-93.

52 Haag M, Fautrel A, Guillouzo A, Frossard N, Pons F. Expression of cytochromes P450 3A in mouse lung: effects of dexamethasone and pregnenolone 16alpha-carbonitrile. Arch Toxicol 2003; 77: 145-9.

53 Meredith C, Scott MP, Renwick AB, Price RJ, Lake BG. Studies on the induction of rat hepatic CYP1A, CYP2B, CYP3A and CYP4A subfamily form mRNAs in vivo and in vitro using precision-cut rat liver slices. Xenobiotica 2003; 33: 511-27.

54 Hosoe TN, Inouye TY. Divergent modes of induction of rat hepatic and pulmonary CYP3A1 by dexamethasone and pregnenolone16alphacarbonitrile. J Health Sci 2005; 51: 75-9.

55 Shah YM, Ma X, Morimura K, Kim I, Gonzalez FJ. Pregnane X receptor activation ameliorates DSS-induced inflammatory bowel disease via inhibition of NF-kappaB target gene expression. Am J Physiol Gastrointest Liver Physiol 2007; 292: G1114-22.

56 Pascussi JM, Gerbal-Chaloin S, Drocourt L, Assenat E, Larrey D, Pichard-Garcia L, et al. Cross-talk between xenobiotic detoxication and other signalling pathways: clinical and toxicological consequences. 
Xenobiotica 2004; 34: 633-64.

57 Duret C, Daujat-Chavanieu M, Pascussi JM, Pichard-Garcia L, Balaguer $\mathrm{P}$, Fabre JM, et al. Ketoconazole and miconazole are antagonists of the human glucocorticoid receptor: consequences on the expression and function of the constitutive androstane receptor and the pregnane X receptor. Mol Pharmacol 2006; 70: 329-39.

58 Kliewer SA, Moore JT, Wade L, Staudinger JL, Watson MA, Jones SA, et al. An orphan nuclear receptor activated by pregnanes defines a novel steroid signaling pathway. Cell 1998; 92: 73-82.

59 Blumberg B, Sabbagh W Jr, Juguilon H, Bolado J Jr, van Meter CM, Ong ES, et al. SXR, a novel steroid and xenobiotic-sensing nuclear receptor. Genes Dev 1998; 12: 3195-205.

60 Schuetz EG, Schmid W, Schutz G, Brimer C, Yasuda K, Kamataki $\mathrm{T}$, et al. The glucocorticoid receptor is essential for induction of cytochrome $\mathrm{P}-4502 \mathrm{~B}$ by steroids but not for drug or steroid induction of CYP3A or P-450 reductase in mouse liver. Drug Metab Dispos 2000; 28: 268-78.

61 Pierrat OA, Mikitova V, Bush MS, Browning KS, Doonan JH. Control of protein translation by phosphorylation of the mRNA 5'-cap-binding complex. Biochem Soc Trans 2007; 35 (Pt 6): 1634-7.

62 Gygi SP, Rochon Y, Franza BR, Aebersold R. Correlation between protein and mRNA abundance in yeast. Mol Cell Biol 1999; 19: 1720-30.

63 Ganem LG, Trottier E, Anderson A, Jefcoate CR. Phenobarbital induction of CYP2B1/2 in primary hepatocytes: endocrine regulation and evidence for a single pathway for multiple inducers. Toxicol Appl Pharmacol 1999; 155: 32-42.

64 Joannard F, Galisteo M, Corcos L, Guillouzo A, Lagadic-Gossmann D. Regulation of phenobarbital-induction of CYP2B and CYP3A genes in rat cultured hepatocytes: involvement of several serine/threonine protein kinases and phosphatases. Cell Biol Toxicol 2000; 16:
325-37.

65 Schuetz EG, Guzelian PS. Induction of cytochrome P-450 by glucocorticoids in rat liver. II. Evidence that glucocorticoids regulate induction of cytochrome P-450 by a nonclassical receptor mechanism. J Biol Chem 1984; 259: 2007-12.

66 Debri K, Boobis AR, Davies DS, Edwards RJ. Distribution and induction of CYP3A1 and CYP3A2 in rat liver and extrahepatic tissues. Biochem Pharmacol 1995; 50: 2047-56.

67 Meyer UA, Hoffmann K. Phenobarbital-mediated changes in gene expression in the liver. Drug Metab Rev 1999; 31: 365-73.

68 Swales K, Plant N, Ayrton A, Hood S, Gibson G. Relative receptor expression is a determinant in xenobiotic-mediated CYP3A induction in rat and human cells. Xenobiotica 2003; 33: 703-16.

69 Lothstein L, Hsu SI, Horwitz SB, Greenberger LM. Alternate overexpression of two P-glycoprotein [corrected] genes is associated with changes in multidrug resistance in a $\mathbf{J} 774.2$ cell line. J Biol Chem 1989; 264: 16054-8.

70 Courtois A, Payen L, Le Ferrec E, Scheffer GL, Trinquart Y, Guillouzo $A$, et al. Differential regulation of multidrug resistance-associated protein 2 (MRP2) and cytochromes P450 2B1/2 and 3A1/2 in phenobarbital-treated hepatocytes. Biochem Pharmacol 2002; 63: 333-41.

71 Wang H, Faucette S, Sueyoshi T, Moore R, Ferguson S, Negishi M, et al. A novel distal enhancer module regulated by pregnane $X$ receptor/constitutive androstane receptor is essential for the maximal induction of CYP2B6 gene expression. J Biol Chem 2003; 278 : 14146-52.

72 Cui J, Heard TS, Yu J, Lo JL, Huang L, Li Y, et al. The amino acid residues asparagine 354 and isoleucine 372 of human farnesoid $X$ receptor confer the receptor with high sensitivity to chenodeoxycholate. J Biol Chem 2002; 277: 25963-9. 